Summer 2019

\title{
Do Accounting Firm Consulting Revenues Affect Audit Quality? Evidence from the Pre- and Post-SOX Eras
}

Ling Lei Lisic

Linda A. Myers

Robert Pawlewicz

University of North Dakota, robert.pawlewicz@UND.edu

Timothy A. Seidel

How does access to this work benefit you? Let us know!

Follow this and additional works at: https://commons.und.edu/acc-fac

Part of the Accounting Commons

\section{Recommended Citation}

Ling Lei Lisic, Linda A. Myers, Robert Pawlewicz, et al.. "Do Accounting Firm Consulting Revenues Affect Audit Quality? Evidence from the Pre- and Post-SOX Eras" (2019). Accountancy Faculty Publications. 5. https://commons.und.edu/acc-fac/5

This Article is brought to you for free and open access by the Department of Accountancy at UND Scholarly Commons. It has been accepted for inclusion in Accountancy Faculty Publications by an authorized administrator of UND Scholarly Commons. For more information, please contact und.commons@library.und.edu. 


\title{
Do Accounting Firm Consulting Revenues Affect Audit Quality? Evidence from the Pre- and Post-SOX Eras
}

\author{
Ling Lei Lisic \\ Pamplin College of Business \\ Virginia Polytechnic Institute and State University \\ llisic@vt.edu \\ Linda A. Myers \\ Haslam College of Business \\ University of Tennessee, Knoxville \\ lmyers16@utk.edu \\ Robert Pawlewicz \\ School of Business \\ George Mason University \\ rpawlewi@gmu.edu \\ Timothy A. Seidel \\ BYU Marriott School of Business \\ Brigham Young University \\ timseidel@byu.edu
}

November 2017

\footnotetext{
*Accepted by Clive S. Lennox. We thank two anonymous reviewers, Brad Badertscher, Ted Christensen, Jeff Cohen, Andrew Doucet, Michael Drake, Jere Francis, Nick Hallman, Inder Khurana, Kyonghee Kim, Mark Ma, Michael Minnis, Miguel Minutti-Meza, James Myers, Tom Omer, Fellipe Raymundo, Stephen Rowe, Roy Schmardebeck, Jaime Schmidt, Paddy Sivadasan, Nate Stephens, Jake Thornock, Pete Wilson, David Wood, workshop participants at Boston College, Brigham Young University, George Mason University, Hong Kong Polytechnic University, Lancaster University, Louisiana State University, McMaster University, University of Missouri - Columbia, University of Notre Dame, Virginia Polytechnic Institute and State University, and participants at the $21^{\text {st }}$ Illinois Symposium on Audit Research (2014) and the 2015 American Accounting Association Auditing Section Midyear Meeting for helpful comments and suggestions. We also thank Su Chung and Kristina Stuhler for their valuable research assistance. Linda Myers gratefully acknowledges financial support from the Haslam Chair of Business and from the William B. Stokely Faculty Research Fellowship at the University of Tennessee, and from the Garrison/Wilson Chair while at the University of Arkansas.
} 


\title{
Do Accounting Firm Consulting Revenues Affect Audit Quality? Evidence from the Pre- and Post-SOX Eras
}

\begin{abstract}
In recent years, public accounting firms have experienced a steady increase in the proportion of their revenues generated from consulting services. Although growth in consulting revenue following the Sarbanes-Oxley Act (SOX) has been generated primarily from services provided to nonaudit clients, regulators have expressed concerns about the potential implications of this increase for audit quality. In contrast, accounting firms assert that the expertise developed by their consulting professionals helps them to provide better quality audits. We examine the relation between the proportion of accounting firm consulting revenue to total revenue and audit quality and investor perceptions of audit quality. Because SOX drastically altered the source of consulting revenues for public accounting firms, we also separately examine these relations in the pre- and post-SOX eras. We find evidence suggesting that before SOX, higher proportions of audit firm consulting revenues negatively impacted both audit quality and investor perceptions of audit quality. However, we do not find a statistically significant association between audit firm consulting revenues and either audit quality or investor perceptions of audit quality following SOX. Our analyses suggest that even if these relations exist following SOX, the potential economic magnitude of the effect is small.
\end{abstract}

Keywords: accounting firms, audit quality, consulting services, nonaudit services

JEL classifications: M41, M42 


\section{Introduction}

Over the past decade, public accounting firms have experienced a steady increase in the proportion of their revenues generated from consulting services. In fact, by 2015, the largest U.S. public accounting firms were generating more revenue from consulting services than from assurance services. Proponents of accounting firms' expansion of consulting services argue that providing consulting services can improve audit quality and thereby benefit investors. However, the Public Company Accounting Oversight Board (PCAOB) has expressed concerns about this trend. For example, in its five-year strategic plan for 2015 through 2019, the PCAOB suggests that it has the opportunity to further its mission by addressing the expansion of consulting services at large accounting firms, and it identifies difficulties in understanding the implications of the expansion of consulting services for audit quality as a threat to achieving its mission. ${ }^{1}$

The debate over whether providing consulting services impairs audit quality has intensified during the past decade. On the one hand, the Advisory Committee on the Auditing Profession (ACAP) and some academics argue that expanding the provision of consulting services can divert resources (e.g., attention, investments, and personnel) away from the assurance practice and potentially alter perceptions of accounting firm identity as well as how accounting firm professionals view their clients (ACAP 2008; Hermanson 2009; Dey et al. 2012). Social identity theory suggests that individuals within an organization are prone to adopt the mindset or attitude perceived as characteristic of the organization (Ashforth and Mael 1989). This view suggests that expanding consulting services could undermine audit quality. On the other hand, a theoretical model developed by Fischer and Huddart (2008) suggests that strong social norms related to professionalism can guard against a deterioration in audit quality in dual-

\footnotetext{
${ }^{1}$ See https://pcaobus.org/About/Administration/Documents/Strategic\%20Plans/2015-2019.pdf.
} 
service accounting firms. Accounting firms also assert that consulting staff often provide valuable insights to the assurance practice because they act as specialists on audit engagements. ${ }^{2}$ Additionally, provisions of the Sarbanes-Oxley Act of 2002 (SOX) restrict public accounting firms to offering very limited types of consulting services to public audit clients. ${ }^{3}$ These factors suggest an alternative view - that expanding consulting services could instead improve audit quality. A final possibility is that the improved insights from specialists could offset any diversion of resources such that increased consulting services would have no detectable effect on audit quality. We contribute to this debate by providing archival evidence on the association between the proportion of accounting firm revenues generated from consulting services (at the U.S. audit firm level) and both audit quality and perceptions of audit quality.

Pre-SOX, public accounting firms derived substantial revenues from providing consulting services, with a sizeable portion coming from their audit clients. However, because of growing pressure from regulators to address real and perceived threats to independence from providing consulting services to audit clients, most large accounting firms divested their consulting practices. In addition, SOX restricted accounting firms from providing a number of nonaudit services to their public audit clients. Since the enactment of SOX, accounting firms have increased their consulting revenues by performing consulting services for nonaudit clients,

\footnotetext{
${ }^{2}$ For example, Deloitte and PricewaterhouseCoopers (PwC) both state that they utilize their consulting professionals as specialists on audit engagements and that this improves the quality of their audits (see, e.g., "Audit Quality: Our Responsibility, Our Commitment”, available at http://www.deloitte.com/assets/Dcom-UnitedStates/Local\%20Assets /Documents/AERS/us_aers_audit_quality_report_011314.pdf, and “Our Focus on Audit Quality: 2013 Report”, available at http://www.pwc.com/en_US/us/audit-assurance-services/publications/assets/2013-audit-qualityreport.pdf).

${ }^{3}$ SOX prohibits public accounting firms from providing a wide range of consulting services to their public audit clients. Although we cannot directly observe the portion of consulting revenues generated by providing consulting services to private audit clients, the AICPA Code of Professional Conduct (Rule 101-3: Nonattest Services) instituted many of the same restrictions as SOX on the provision of consulting services to private audit clients. Our conversations with experienced Big 4 consulting personnel indicate that the majority of consulting revenues are generated from public nonaudit clients rather than private clients. As such, we attribute the growth in consulting revenue in recent years to consulting services provided to nonaudit clients.
} 
allowing them to avoid concerns related to impaired independence. However, the academic research to date focuses exclusively on nonaudit services provided to public audit clients (and provides mixed evidence regarding its impact on audit quality). Whether consulting services provided to nonaudit clients impair audit quality remains an open and important empirical question because both independence impairment concerns and the potential for knowledge spillovers of client-specific information do not exist when accounting firms provide consulting services to nonaudit clients. Therefore, our study addresses questions that have received regulatory, academic, and practitioner attention, but have not yet been examined empirically.

Accounting Today publishes an annual list of the largest 100 public accounting firms in the U.S., ranked by total revenues. This list provides the proportion of each firm's revenues generated from audit and assurance (A\&A), tax, management advisory services (MAS), and other services. We use this list to measure each accounting firm's consulting services as the proportion of its U.S. revenues derived from MAS and other services. ${ }^{4}$ Using this measure, we first examine the association between accounting firm revenues generated from consulting services and audit quality, where we use annual financial statement misstatements as revealed through subsequent restatements to proxy for audit quality. Additionally, because SOX drastically altered the source of consulting revenues for public accounting firms and increased public company audit regulation, we examine these relations both before and after SOX.

Overall, our results suggest that before SOX, when public audit clients provided an important source of consulting revenues, higher levels of accounting firm consulting revenues negatively impacted audit quality. However, following SOX, we do not find a statistically

\footnotetext{
${ }^{4}$ Although our consulting services measure includes revenues from other services, the proportion of revenues derived from other services is small, averaging only 9.2 percent of revenues for Accounting Today's Top 100 firms from 2000 through 2013. Our inferences are robust to measuring consulting services as the proportion of an accounting firm's U.S. revenues derived from MAS only.
} 
significant association between consulting revenues and audit quality. Our analyses suggest that even if this relation does exist post-SOX, the potential economic magnitude of the effect is small. In additional analyses, we also find that pre-SOX, audit quality was lower when accounting firms generated the majority of their revenues from consulting services and when increases in accounting firm revenues generated from consulting services were larger. However, post-SOX, we do not find a statistically significant association between audit quality and these measures of consulting revenues. Our inferences remain unchanged when we examine only misstatements identified through Item 4.02 non-reliance restatements and when we perform analyses at the audit firm-year level using Big $\mathrm{N}$ and second tier audit firms. As such, our collective evidence suggests that the recent growth in accounting firm consulting revenues, which are generated primarily from nonaudit clients, has not resulted in an economically significant deterioration in audit quality.

Next, we examine whether investors perceive accounting firms' provision of consulting services as improving or impairing audit quality. We use annual short-window earnings response coefficients (ERCs) to proxy for market perceptions of audit quality following Francis and Ke (2006) and Ghosh et al. (2009). Similar to our audit quality tests, we find that before SOX, ERCs are smaller when a greater proportion of audit firm revenue is derived from consulting services. These results suggest that before SOX, capital market participants perceived a deterioration of audit quality when a higher proportion of accounting firm revenues were generated from consulting. Following SOX, we do not find a statistically significant association between consulting revenues and short-window ERCs. Our analyses again suggest that even if this relation does exist post-SOX, the potential economic magnitude of the effect is small. 
Our paper contributes to the academic literature and provides valuable information to regulators, accounting firms, and investors. First, we contribute to the ongoing debate regarding whether public accounting firms’ expansion of consulting services impacts audit quality. Our results suggest that when audit clients are an important source of consulting revenues, these revenues negatively impact audit quality and perceptions of audit quality but when consulting revenues come primarily from nonaudit clients, these revenues have little to no detectable economic effect on audit quality or perceptions of audit quality. Second, because the expansion of consulting revenues post-SOX is primarily attributable to consulting provided to nonaudit clients, our study addresses questions that have received regulatory and academic attention, but have not yet been examined empirically.

Our paper also contributes to research examining the effect of non-tax, non-audit services on engagement-level audit quality. Paterson and Valencia (2011) find a positive relation between certain audit-related non-audit services and misstated years that are subsequently restated after the enactment of SOX. Consistent with this, we find that, following SOX, higher levels of advisory and other non-tax, non-audit services not only increase the likelihood of misstatement at the engagement level, but also negatively impact investor perceptions of audit quality (i.e., shortwindow ERCs).

We acknowledge the limitations inherent in our measure of consulting services at the audit firm level. Although our inclusion of all of Accounting Today’s “Top 100” firms with available data provides some variation in our variable of interest, this variation is somewhat limited because a large percentage of the sample are clients of the Big 4 firms. Furthermore, consulting revenue is not available from the accounting firms at more granular levels (e.g., at the office level, partner level, or by service type). 
The remainder of the paper is organized as follows. Section 2 describes the background and reviews related literature. Section 3 develops our hypotheses. Section 4 discusses our research design. Section 5 describes our sample and summary statistics. Section 6 presents our empirical results and Section 7 concludes.

\section{Background and Related Literature}

In the 1980s and 1990s, public accounting firms derived substantial revenues from consulting services, with a sizeable portion coming from their audit clients. ${ }^{5}$ Assurance engagements were sometimes characterized as 'loss leaders,' designed to secure more lucrative consulting engagements. Consulting engagements were highly profitable and experienced growth rates nearly double those of typical audit work. ${ }^{6}$

Regulators, investors, and academics have long debated whether the provision of nonaudit services to audit clients impairs audit quality. Public accounting firms argue that the provision of nonaudit services to audit clients produces knowledge spillovers that increase both the effectiveness and efficiency of audits (Simunic 1984). Regulators, however, argue that the provision of nonaudit services to audit clients strengthens the economic bond between accounting firms and their clients, thereby threatening auditor independence (Panel on Audit Effectiveness 2000).

In the late 1990s and early 2000s, accounting firms faced growing pressure from the U.S. Securities and Exchange Commission (SEC) and from investors to address perceived conflicts of interest resulting from providing consulting services to audit clients. As a result, most large

\footnotetext{
${ }^{5}$ See "BearingPoint: The End of an Era" in AccountingWEB.com (2009); available at: http://www.accountingweb.com/topic/firm-news/bearingpoint-end-era. ${ }^{6}$ See “Cap Gemini Merges with EY Consulting” in AccountingWEB.com (2000); available at: http://www.accountingweb.com/topic/firm-news/cap-gemini-merges-ey-consulting.
} 
accounting firms divested their consulting practices. ${ }^{7}$ Additionally, SOX restricted accounting firms from providing most nonaudit services to their public audit clients. ${ }^{8}$ The restrictions imposed by SOX and the divestiture of the consulting practices combined to significantly reduce the amount of consulting revenues earned by public accounting firms in the early 2000s and alter the source of the consulting revenues afterwards. Since then, accounting firms have expanded their consulting revenues by performing consulting services for nonaudit clients, which allows them to avoid the appearance of impaired independence.

Over the past decade, many of the large accounting firms have rebuilt their consulting practices both organically and through acquisitions. ${ }^{9}$ In a December 2014 speech at the AICPA Conference on Current SEC and PCAOB Developments, PCAOB Chairman Doty cautioned against the marked reduction in audit revenues, especially for the global, networked accounting firms. ${ }^{10}$ Similarly, in a October 2016 speech at the NYSSCPA SEC Conference, PCAOB Board Member Steven Harris discussed the rise of consulting and advisory services in audit firms as one of the PCAOB's current priorities. ${ }^{11}$

\footnotetext{
${ }^{7}$ Specifically, Ernst \& Young (in 2000), KPMG (in 2001), Andersen (in 2001), and PwC (in 2002) all sold or spunoff their consulting practices, making Deloitte the only Big 5 accounting firm to retain its consulting practice. See Dey et al. (2012) for a detailed discussion of the divestiture process at each firm.

${ }^{8}$ Specifically, SOX Section 201(a) prohibits the provision of the following nonaudit services to audit clients: “(1) bookkeeping or other services related to the accounting records or financial statements of the audit client; (2) financial information systems design and implementation; (3) appraisal or valuation services, fairness opinions, or contribution-in-kind reports; (4) actuarial services; (5) internal audit outsourcing services; (6) management or human resources; (7) broker or dealer, investment adviser, or investment banking services; (8) legal services and expert services unrelated to the audit; and 9) any other service that the Board determines, by regulation, is impermissible" (United States Code 2002, 771). However, all services not specifically banned by SOX are still permitted with audit committee pre-approval. These services include, but are not limited to, providing comfort letters to debt holders, assistance in making regulatory filings, due diligence and transaction support, forensic services, pension advisory services, and other attestation work outside of the audit.

${ }^{9}$ See, for example, "Deloitte Agrees to Buy BearingPoint Unit" in the NYTimes.com, available at http://dealbook.nytimes.com/2009/03/24/deloitte-agrees-to-buy-bearingpoint-unit/. In this deal, Deloitte purchased KPMG's former consulting practice. Also see "Pricewaterhouse to Buy Booz Consulting Firm" in the New York Times (October 31, 2013, sec. B).

${ }^{10}$ See http://pcaobus.org/News/Speech/Pages/12082014_Doty_AICPA.aspx.

${ }^{11}$ See https://pcaobus.org/News/Speech/Pages/Harris-speech-NYSSCPA-10-25-16.aspx.
} 
Academic research to date focuses exclusively on nonaudit services provided to audit clients and provides mixed evidence regarding the impact on audit quality. Frankel et al. (2002) find that nonaudit fees billed to audit clients are positively associated with earnings management proxies, and Krishnan et al. (2011) find a positive association between pre-SOX absolute discretionary accruals and the magnitude of the decline in nonaudit fees in the post-SOX period. Kinney et al. (2004) find a positive association between restatements and unspecified non-audit services prior to SOX. Findings in these studies are consistent with the argument that, in the preSOX period, greater dependence on nonaudit fees resulted in lower audit quality. Beardsley et al. (2016) suggest that in the mid-2000's, audit offices increased the sale of nonaudit services to audit clients as a way to compensate for audit fee pressure, and the combination of audit fee pressure and the increased focus on nonaudit services results in lower audit quality, as proxied by the rate of client misstatements. Similarly, Paterson and Valencia (2011) find a positive association between restatements and audit-related and other non-audit service revenues from 2003 through 2006. They also find that the association is larger for non-recurring audit-related non-audit services than for recurring audit-related services.

A number of other studies document contrary evidence. Using pre-SOX data, Nam and Ronen (2012) and Koh et al. (2013) find evidence of improved financial statement quality as clients pay greater amounts of nonaudit fees to their auditors. Ashbaugh et al. (2003) and Chung and Kallapur (2003), however, do not find an association between the provision of nonaudit services to audit clients and earnings quality. Using a difference-in-differences design, Lennox (2016) finds no change in audit quality (measured using misstatements, tax-related misstatements, and going concern opinions) following a quasi-exogenous shock to the amount of 
auditor-provided tax services. In addition, DeFond et al. (2002) do not find a relation between nonaudit fees and auditors’ propensity to issue going concern opinions to distressed clients.

To our knowledge, prior research is silent on the impact of audit firm-level consulting revenues on audit quality. Additionally, because SOX prohibits public accounting firms from providing a host of consulting services to their audit clients, the expansion of the consulting revenues over the past decade derives largely from nonaudit clients. To our knowledge prior research has not examined the impact of consulting services provided to nonaudit clients on audit quality. Whether consulting services provided to nonaudit clients impair audit quality is an important empirical question because both independence impairment concerns and the potential for knowledge spillovers of client-specific information do not exist when accounting firms provide consulting services to nonaudit clients. Therefore, any findings from prior literature would not necessarily generalize to our setting.

\section{Development of Hypotheses}

According to Ashforth and Mael (1989, 26-27), “social identification enables the individual to feel loyal to an organization or corporate culture... the individual typically adopts those characteristics perceived as prototypical of the groups with which he or she identifies... this identity may be reflected in shared values and beliefs ... organizational climate, and so on.” Social identity theory suggests that higher levels of audit firm consulting revenue could affect the attitudes and mindsets of individual auditors, leading to an increased focus on client satisfaction and a reduction in the skeptical evaluation of audit evidence. Fischer and Huddart (2008) develop a principal-agent model to investigate how endogenous social norms influence the decisions of professionals. Specifically, they model how the social norms of the audit practice, which rely on using sound accounting judgment and high professional standards, compete with 
incentives of the consulting practice, which center on providing client satisfaction, in dualservice public accounting firms. They suggest that in these accounting firms, high social norms related to accounting professionalism can create strong incentives for high audit quality among audit personnel but if the incentives provided by the consulting practice are more powerful than the social norms related to professionalism, then audit quality can suffer. In this study, we empirically investigate whether an increased focus on generating consulting revenues appears to have eroded the social norms within accounting firms such that audit quality has been impaired.

On the one hand, regulators and academics suggest that accounting firms' increased focus on providing consulting services has eroded the professionalism (or social norms) of accounting firms in a number of ways. For example, Arthur Wyatt, a former Senior Partner and Managing Director at Arthur Andersen LLP, asserts that his former firm's “commercial interests had undermined the core values of the professional firm” (Wyatt 2004, 50). Although SOX changed the source of consulting revenues, in their 2008 report to the U.S. Department of the Treasury, ACAP asserted that the expansion of consulting services to nonaudit clients merely substituted concerns regarding resource diversion for concerns regarding auditor independence (ACAP 2008). Additionally, Hermanson (2009) outlines other ways in which an increased focus on consulting can erode accounting firm professional norms. These include causing confusion about who the accounting firm's client is (i.e., management versus investors and the audit committee), creating intra-firm conflicts about compensation of audit versus consulting professionals, and increasing profit pressure, which distracts audit professionals from focusing on audit quality. Finally, Dey et al. (2012) suggest that large accounting firms may be tempted to shed audit 
clients in order to expand their base of potential consulting clients because consulting engagements are typically more profitable than audit engagements. ${ }^{12}$

On the other hand, some practitioners and accounting firms assert that the provision of consulting services can enhance audit quality. For example, Goldwasser (2002) suggests that nonaudit service revenues improve the viability of the public accounting industry and relieve price competition for audit services. Additionally, accounting firms promote the idea that the expertise developed by their consulting professionals can improve the quality of audit engagements that utilize these consultants as specialists. Specifically, in accordance with AU 336.03(c), ${ }^{13}$ Using the Work of a Specialist, accounting firms can assign personnel from their consulting practices to act as specialists on their audit engagement teams. ${ }^{14}$ Moreover, in its 2013 audit quality report, Deloitte states that the use of its financial advisory, tax, and consulting professionals as specialists on audit engagements is "an indispensable asset that contributes to the quality of our audits” and in its 2013 audit quality report, PwC explains that by utilizing the knowledge of its consultants as specialists, audit teams are able to "better evaluate complex transactions, assess accounting treatments, and identify areas where additional professional skepticism may be warranted.”15 The PwC report goes on to identify information technology (IT) specialists as a group that substantially improves audit quality because they assist audit teams in

\footnotetext{
${ }^{12}$ Consistent with this, PwC's former client Hillshire Brands Co. recently announced that PwC would no longer be its auditor because the company had a consulting agreement with Booz (which PwC acquired in April 2014). See "PricewaterhouseCoopers Renaming Booz \& Co. as 'Strategy\&'” in the Wall Street Journal, available at http://online.wsj.com/news/articles/SB10001424052702303987004579477642677243618.

${ }^{13}$ AU 336.03(c) will become AS 1210.03(c) in the reorganized PCAOB auditing standards, which become effective at the end of 2016.

${ }^{14}$ For example, an audit engagement team for a manufacturing client can use a valuation specialist from its financial services advisory practice to assist with evaluating management's assertions related to the valuation, presentation, and disclosure of financial derivatives.

${ }^{15}$ See page 13 of “Audit Quality: Our Responsibility, Our Commitment”, available at http://www.deloitte.com/ assets/Dcom-UnitedStates/Local\%20Assets/Documents/AERS/us_aers_audit_quality_report_011314.pdf, and page 19 of “Our Focus on Audit Quality: 2013 Report”, available at http://www.pwc.com/en_US/us/audit-assuranceservices/publications/assets/2013-audit-quality-report.pdf.
} 
understanding complex IT internal control systems. In fact, consulting professionals play a sizeable role on audit engagement teams and their work comprised approximately 10 percent of PwC's total engagement hours in 2013. ${ }^{16}$ Finally, Fischer and Huddart (2008) point out that dual-service accounting firms can install additional control systems to promote high audit quality.

Because the provision of consulting services can have either a detrimental or beneficial effect on audit quality, we state our first hypothesis in the null form as follows:

HYPOTHESIS 1a. The proportion of accounting firm revenue generated from consulting services is not associated with audit quality.

We also examine the relation between the proportion of accounting firm revenue generated from consulting services and audit quality in the pre- and post-SOX periods. Prior to SOX, public audit clients provided an important source of consulting revenues, while much of the growth in consulting revenues post-SOX comes from nonaudit clients due to limitations imposed by SOX. As such, following SOX, independence impairment is less of a concern and the potential for client-specific knowledge spillovers is greatly reduced. In addition, SOX brought significant reform to public company auditor oversight through the formation of the PCAOB. Accounting firms assert that the PCAOB inspection process has improved the quality of their audits. ${ }^{17}$ Given the nature of the changes brought about by SOX, it is not clear whether any pre-SOX relation between audit quality and the proportion of accounting firm revenue

\footnotetext{
${ }^{16}$ See page 19 of “Our Focus on Audit Quality: 2013 Report”, available at http://www.pwc.com/en_US/us/auditassurance-services/publications/assets/2013-audit-quality-report.pdf.

${ }^{17}$ For example, on page 21 of an Ernst \& Young publication about their commitment to audit quality, available at http://www.ey.com/Publication/vwLUAssets/ey-our-commitment-to-audit-quality/\$FILE/ey-our-commitment-toaudit-quality.pdf, the firm states, "We want to drive further improvements in audit quality and are fully committed to doing so. We value the PCAOB inspection process because it helps us identify areas where we can continue to improve our performance.”
} 
generated from consulting services would hold post-SOX. This discussion leads to the following null hypotheses:

HYPOTHESIS 1b. The proportion of accounting firm revenue generated from consulting services is not associated with audit quality pre-SOX.

HYPOTHESIS 1c. The proportion of accounting firm revenue generated from consulting services is not associated with audit quality post-SOX.

In addition to evaluating whether consulting services impact audit quality, we examine whether consulting services enhance or impair investor perceptions of audit quality. Prior studies use ERCs (i.e., the impact of earnings news on investor beliefs about company value) to proxy for investor perceptions of audit quality. For example, Teoh and Wong (1993) interpret the higher ERCs of clients that engage Big $\mathrm{N}$ audit firms as suggesting that investors perceive audit firm size to enhance audit quality, presumably because Big N audit firms have “deeper pockets” and more reputational capital at stake.

In our setting, if investors perceive audit quality to be lower (either due to potential resource diversion or changing social norms) when accounting firms generate a greater proportion of their revenues from consulting services, ERCs should be attenuated. Conversely, if investors perceive audit quality to be higher (because audit firms can use consulting personnel to provide specialist knowledge on audit engagements) when accounting firms generate a greater proportion of their revenues from consulting services, ERCs should be enhanced.

Because the provision of consulting services can have a detrimental or beneficial effect on investor perceptions of audit quality, we state our second hypothesis in the null, as follows:

HYPOTHESIS 2a: The proportion of accounting firm revenue generated from consulting services is not associated with investor perceptions of audit quality.

As previously discussed, given the nature of the changes brought about by SOX, it is not clear whether any pre-SOX relation between the proportion of accounting firm revenue 
generated from consulting services and investor perceptions of audit quality would hold post-

SOX. Therefore, we present the following null hypotheses:

HYPOTHESIS 2b. The proportion of accounting firm revenue generated from consulting services is not associated with investor perceptions of audit quality pre-SOX.

HYPOTHESIS 2c. The proportion of accounting firm revenue generated from consulting services is not associated with investor perceptions of audit quality post-SOX.

\section{Research Design}

\section{Tests of Audit Quality}

We proxy for audit quality using misstatements (as revealed through subsequent financial statement restatements). Christensen et al. (2016) find that auditors and investors view financial statement restatements as the leading indicator of low audit quality. Additionally, Aobdia (2017) finds that among audit quality proxies used in the archival audit literature, restatements are best able to predict PCAOB inspection report Part I findings. Finally, auditing standards require the auditor to plan and perform the audit to obtain reasonable assurance about whether the annual financial statements are free of material misstatement (PCAOB 2003). As such, annual financial statement restatements provide direct evidence of a misstatement that was not detected and reported. For these reasons, financial statement restatements are often used in academic studies to identify lower audit quality (e.g., Kinney et al. 2004; Stanley and DeZoort 2007; Schmidt 2012; Francis and Michas 2013).

To test our first set of hypotheses, we estimate the following model, with standard errors clustered by client:

$$
\begin{aligned}
\operatorname{Pr}\left(\text { Misstate }_{i t}=\right. & 1)=\alpha_{0}+\alpha_{1} \% \text { MAS }_{j t-1}+\alpha_{2} \text { MAS_client } \\
& +\alpha_{3} \text { Tax_client }_{i t}+\alpha_{4} \text { LnAFEE }_{i t} \\
& +\alpha_{5} \text { BigN }_{i t}+\alpha_{6} \text { SecondTier }_{i t}+\alpha_{7} \text { Specialist }_{i t}+\alpha_{8} \text { SQRTTenure }_{i t}+\alpha_{9} \text { ICMW }_{i t} \\
& +\alpha_{10} \text { LnAssets }_{i t}+\alpha_{11} \text { Leverage }_{i t}+\alpha_{12} \text { MTB }_{i t}+\alpha_{13} \text { FIN }_{i t}+\alpha_{14} \text { FREEC }_{i t} \\
& +\alpha_{15} \text { M\&A }_{i t}+\alpha_{16} \text { ROA }_{i t}+\alpha_{17} \text { Loss }_{i t}+\alpha_{18} \text { ARINV }_{i t}+\alpha_{19} \text { VarReturn }_{i t} \\
& +\alpha_{20} \text { OffSize }_{i t}+\alpha_{\mathrm{j}} \text { Industry FE }+\alpha_{\mathrm{k}} \text { Year FE }+\varepsilon_{\mathrm{it}}
\end{aligned}
$$

where: 
Misstate $=$ an indicator variable set equal to one if the annual financial statements were misstated (as revealed through a subsequent restatement), and zero otherwise (restatement data from Audit Analytics); ${ }^{18}$

$\% M A S=$ the proportion of U.S. management advisory and other fees (i.e., consulting revenues) to total U.S. revenue, calculated at the accounting-firm level as (MAS + Other fees) / (Audit + Tax + MAS + Other fees) from Accounting Today;

and control variables are defined in the Appendix.

The coefficient of interest is $\alpha_{1}$, the coefficient on $\% M A S$. Because providing a high proportion of consulting services is unlikely to have an immediate effect on an accounting firm's social norms and culture, especially if the source and amount of revenues earned by the firm are reported only annually within the organization, we estimate equation (1) using the audit firm’s one-year lagged consulting to total revenue ratio. ${ }^{19}$ The control variables follow prior literature (e.g., Dechow et al. 1996; Summers and Sweeney 1998; Kinney et al. 2004; Blankley et al. 2012; Cao et al. 2012; Lobo and Zhao 2013) to the extent that these variables are widely available for our sample. Coefficient estimates $\alpha_{2}$ and $\alpha_{3}$ control for potential independence impairment or knowledge spillover generated by MAS/other and tax services performed for the audit client. To test Hypothesis 1b and Hypothesis 1c, we estimate equation (1) separately using pre-SOX and post-SOX sample partitions.

\section{Tests of Perceptions of Audit Quality}

\footnotetext{
${ }^{18}$ In untabulated analyses, we include only non-clerical error misstatements and our inferences are unchanged.

${ }^{19}$ In sensitivity analyses, we examine the effect of the audit firm's contemporaneous and two-year lagged consulting to total revenue ratios and our inferences are unchanged.
} 
Following Francis and Ke (2006) and Ghosh et al. (2009), we use short-window ERCs in the three days around the announcement of annual earnings to proxy for market perceptions of audit quality. ${ }^{20}$ Here, we estimate the following model, with standard errors clustered by client:

$$
\begin{aligned}
C A R= & \beta_{0}+\beta_{1} F E R R+\beta_{2} \% M A S_{j t-1}+\beta_{3} F E R R \times \% M A S_{j t-1}+\beta_{4} X+\beta_{5} \text { Industry FE } \\
& +\beta_{6} \text { Year FE }+\beta_{7} F E R R \times X+\beta_{8} F E R R \times \text { Industry FE }+\beta_{9} F E R R \times \text { Year FE }+\varepsilon_{\mathrm{it}}
\end{aligned}
$$

where:

CAR = abnormal (market-adjusted) returns cumulated over days $[-1,+1]$ relative to the annual earnings announcement;

FERR = analyst forecast error, measured as the difference between reported annual earnings per share and the most recent median consensus analyst earnings forecast, deflated by stock price at the end of the fiscal year;

$\%$ MAS = as previously defined; and

control variables are defined in the Appendix.

We measure \%MAS, MAS_client, and Tax_client at the end of the previous year so that the information is available to investors. Consistent with prior research, the ERC is the coefficient on FERR. The impact of consulting services on the ERC (Hypothesis 2a) is captured by $\beta_{3}$; a positive (negative) value would indicate that consulting services enhance (impair) the market's perception of audit quality.

To test Hypothesis $2 \mathrm{~b}$ and Hypothesis 2c, we estimate equation (2) separately using the pre-SOX and post-SOX sample partitions. Our control variables follow prior literature (e.g., Francis and Ke 2006; Ghosh et al. 2009) and, again, we control for potential independence impairment or knowledge spillovers from providing MAS/other or tax services to the audit

\footnotetext{
${ }^{20}$ Note that this test assumes that investors are aware of the growth in accounting firm consulting practices. This is likely because industry analysts and the media comment on recent growth in consulting revenues. See, for example, IBISWorld Industry Report 54121c: Accounting Services in the U.S. (June 2014), available at: http://clients1.ibisworld.com/reprots/us/industry/default.aspx?entid=1398.
} 
client. We include year fixed effects to control for variation in ERCs over time that are unrelated to variation in accounting firm consulting revenues.

\section{Sample Selection and Summary Statistics}

We collect public accounting firms’ annual revenue from Accounting Today’s “Top 100 Firms” reports. Accounting Today is a monthly trade magazine, distributed through Lexis Nexis, Business Source Complete, and other databases, that focuses on tax and accounting news. Accounting Today publishes the “Top 100 Firms” ranking annually using the accounting firms’ self-reported U.S. revenues. The rankings present total revenue as well as the percentage of revenue from A\&A, tax, and MAS business lines. Because audit and non-audit fee disclosures were not available for U.S. public companies until 2000 and because Audit Analytics coverage of restatements is sparse prior to this year, our sample period begins in 2000. We end the sample period in 2013 to allow sufficient time for misstatements to be revealed. For our audit quality tests, our samples are limited to company-year observations with the necessary data from Compustat, Audit Analytics, and the Center for Research in Security Prices (CRSP) to construct our model variables. For our audit quality perception tests, our samples are limited to companyyear observations with the necessary data from Compustat, Audit Analytics, CRSP, and I/B/E/S.

Table 1 presents a summary of our sample selection procedures. Merging company-year observations with fiscal year-ends from 2000 through 2013 from Compustat, Audit Analytics, and CRSP, yields 84,177 company-year observations. Because Accounting Today does not

provide MAS data for KPMG for 2004 through 2006, we remove KPMG clients in 2005 through 2007, where one year lagged MAS data is missing (deleting 3,672 company-year 
observations). ${ }^{21}$ We also remove observations missing data required to construct model variables (27,726 company-year observations), observations where the signing auditor office is located outside of the U.S. (5,751 company-year observations), and observations with missing one-year lagged MAS amounts (164 company-year observations), resulting in a sample of 46,864 company-year observations. ${ }^{22}$ The final sample includes clients of 79 unique audit firms, with 553 unique auditor-year combinations of \%MAS (constructed at the audit-firm level). For our tests of perceptions of audit quality, we begin with the 46,864 company-year observations used in our audit quality tests and retain all observations with data from Compustat, CRSP, and $I / B / E / S$ required to perform our tests. We remove 297 observations with a stock price less than one dollar at the end of the fiscal year, which reduces noise caused by small FERR deflators (Livnat and Mendenhall 2006). ${ }^{23}$ The final sample for our short-window market reaction test consists of 27,124 company-year observations.

[insert Table 1 here]

Figure 1 presents the proportions of revenues from A\&A, tax, and MAS for the “Top 100” U.S. public accounting firms, as reported in Accounting Today, from 2000 through $2015 .{ }^{24}$ While the percentage of revenue from tax services remained between 20 to 35 percent for most of this period, the trends for A\&A and MAS services demonstrate more variation and move inversely. The majority of accounting firm revenue was generated from MAS in 2000 (which pre-dated the divestiture of four of the Big 5 accounting firms' consulting practices and

\footnotetext{
${ }^{21}$ Accounting Today includes KPMG’s MAS revenues in A\&A revenues and reports zero MAS revenues for 2004 through 2006. However, our inferences are robust to including KPMG clients from 2005 through 2007 and using the MAS and A\&A revenues as reported in Accounting Today.

${ }^{22}$ We remove observations where the office is located outside the U.S. because the Accounting Today revenue figures are provided at the U.S. level.

${ }^{23}$ In untabulated tests, inferences are consistent if we include these observations in the sample.

${ }^{24}$ The percentage of revenues derived from A\&A, tax, and MAS differ by audit firm and year. Arthur Andersen LLP is included in the figure from 2000 through 2002.
} 
restrictions on the types of nonaudit services that could be performed for audit clients under SOX). From 2004 through 2009, revenue from MAS fell to as little as 21 percent of total revenue, as accounting firms divested their consulting practices due to the SOX restrictions placed on nonaudit services for public audit clients and an increasing demand for assurance services related to internal controls over financial reporting. Over the same time period, the percentage of A\&A revenue climbed, reaching a peak of almost 54 percent by 2007. Since 2009, the percentage revenue from MAS has increased dramatically, and the percentage of revenue from A\&A has declined. ${ }^{25}$ As of 2015, the percentage of revenue derived from MAS has again become the largest source of revenue for the "Top 100" U.S. public accounting firms, slightly outpacing A\&A.

\section{[insert Figure 1 here]}

Although MAS has once again become the largest source of revenue for accounting firms, they now generate MAS revenues from different sources (clients) than was previously the case. For example, the 2000 edition of the “Top 100 Firms” discusses the 'cross-selling' of financial planning, technology, employee benefits, and business valuation consulting services to audit clients as major sources of MAS revenue generation, but SOX prohibited the provision of these services to public audit clients and significantly reduced the extent of nonaudit services provided by accounting firms to their public audit clients (Ghosh and Pawlewicz 2009). It follows that the revenue growth in MAS since 2009 is driven by the provision of consulting services to nonaudit clients. This trend is apparent in Figure 2, which presents the average ratio of non-audit, non-tax fees to total public audit client fees (MAS_client) over the sample period. In 2000, these non-tax-related non-audit fees represented approximately 35 percent of total

\footnotetext{
${ }^{25}$ Dey et al. (2012) discuss how the expiration of the non-compete agreements signed by Ernst \& Young, KPMG, and $\mathrm{PwC}$ with their former consulting arms contributed to the growth in consulting services during this time.
} 
public audit client fees, but from 2003 through 2013, these fees represent less than 3 percent of total public audit client fees, on average. These figures highlight that although public audit clients were an important source of MAS revenues before SOX, MAS revenues following SOX are no longer generated largely from public audit clients.

[insert Figure 2 here]

Panel A of Table 2 presents summary statistics for fee-related variables for client-year observations at the intersection of Accounting Today and Audit Analytics for the full sample (from 2000 through 2013), as well as for the pre- and post-SOX subsamples. Unlike Figure 1, which presents average fee percentages for the Accounting Today “Top 100 Firms,” these statistics are presented for all client observations with available data audited by one of these accounting firms during the sample period. The Accounting Today revenue figures include revenues received from both publicly-traded and private clients while Audit Analytics covers only publicly-traded companies and reports annual audit and audit-related fees, tax fees, and other fees paid to the auditor. Therefore, mean values of \%MAS in Table 2 differ somewhat from percentages in Figure 1.

[insert Table 2 here]

Using the data from Accounting Today, we find that accounting firms' average one-year lagged revenues from consulting services as a percent of total U.S. revenue (\%MAS) is 25.8 percent over our full sample period. Before SOX, this average was much higher, at 43.7 percent, than it is post-SOX, at 20.4 percent (a decrease which is significant at $p<0.001$ ). Using data from Audit Analytics, we also find that, before SOX, 25.9 percent of the total fees paid by public audit clients were for non-tax, nonaudit services, on average, while these same fees account for 
only 1.4 percent of the total fees paid by public audit clients following SOX (a decrease which is significant at $p<0.001)$.

Panel B presents summary statistics for other model variables. We find that 12.4 percent of company-years in the sample are misstated, as identified through a subsequent restatement announcement. When examining the pre- and post-SOX subsamples separately (untabulated), we find that 15.0 percent of observations make misstatements in the pre-SOX period and 11.6 percent of observations make misstatements in the post-SOX period. Descriptive statistics for other model variables are consistent with those from prior research.

Table 3 provides pair-wise correlations between model variables. We find a significant positive correlation between misstatements and the one-year lagged proportion of accounting firm revenue generated from consulting services (\%MAS). We also find a positive correlation between misstatements and the ratio of non-tax, nonaudit fees to total public audit client fees (MAS_client) and between misstatements and public audit client-specific tax fees to total public audit client fees (Tax_client). We find a strong positive correlation between \%MAS and the ratio of non-tax, nonaudit fees to total public audit client fees (MAS_client). In untabulated analysis, we find that this positive correlation is much stronger in the pre-SOX period than in the postSOX period, which is consistent with firms generating more of their non-tax non-audit fees from non-public clients during the post-SOX period. ${ }^{26}$

[insert Table 3 here]

\section{Empirical Results}

\section{Tests of Audit Quality}

\footnotetext{
${ }^{26}$ Specifically, in the pre-SOX period, we find a positive and significant Pearson correlation between \%MAS and MAS_client (of 0.260) and a positive and significant Spearman correlation (of 0.204) but in the post-SOX period, we find a positive and significant Pearson correlation (of 0.046) and a negative and significant Spearman correlation (of -0.019).
} 
Table 4 presents the results from our first hypotheses related to restatements. Using the full sample in Column (1), we find a positive and significant coefficient on \%MAS, which suggests that a higher level of consulting revenue at the audit firm level is positively associated with the likelihood that a financial statement misstatement is not detected and/or reported by the auditor. When partitioning our sample into pre- and post-SOX observations, we find that this relation is statistically significant pre-SOX (as reported in Column 2), but is statistically insignificant post-SOX (as reported in Column 3). Further analysis suggests that the statistically significant result pre-SOX is economically meaningful, while the insignificant result post-SOX is economically inconsequential. Specifically, the percentage change in the odds of a misstatement for a two standard deviation change in $\% M A S_{i t-1}$ in the pre-SOX period is approximately 48 percent, but in the post-SOX period, it is less than one percent. ${ }^{27}$ These results suggest that before SOX, when public audit clients provided an important source of consulting revenues, higher levels of prior year accounting firm consulting revenues negatively impacted audit quality but this relation does not persist after SOX, when regulations restrict public audit clients from providing an important source of consulting revenues. ${ }^{28}$ In the full and post-SOX subsamples, consistent with Paterson and Valencia (2011), we find a positive and significant association between the ratio of client-specific advisory and other fees to total public audit client fees

\footnotetext{
${ }^{27}$ We calculate the percent change in the odds of a misstatement for a two standard deviation change in \%MAS $S_{\text {it- } 1}$ as $\left(100 *\left(\mathrm{e}^{\left(\beta^{*} 2 \text { standard deviations }\right)}-1\right)\right)$. In the pre-SOX period, this equals $48.209\left(100 *\left(\mathrm{e}^{(1.178 * 0.334)}-1\right)\right)$ and in the postSOX period, this equals $0.859\left(100 *\left(\mathrm{e}^{(0.031 * 0.276)}-1\right)\right)$.

${ }^{28}$ Because of the high correlation between \%MAS and MAS_client pre-SOX, we assess whether our results are affected by multicollinearity. We first estimate equation (1) as a linear probability model and examine the variance inflation factors (VIFs). We find VIFs of 1.412 and 1.714 on \%MAS and MAS_client, respectively, and the largest VIF in the model is 4.970 (on BigN). Kennedy (2008) suggests that VIFs of less than 10 do not warrant concerns about multicollinearity. Next, we re-estimate equation (1) for the pre-SOX sample excluding MAS_client. We continue to find a positive and significant coefficient on \%MAS $(1.201$, significant at $\mathrm{p}<0.001)$ and no other model variables are affected.
} 
(MAS_client) and misstatements, suggesting that such services at the engagement-level, although permitted, may threaten audit quality.

[insert Table 4 here]

Because a failure to reject the null hypothesis could occur when no association exists or when tests lack sufficient power to reject the null, we perform several tests to assess the insignificant relation between \%MAS and misstatements following SOX. We first assess whether the results are statistically insignificant because the effects are truly small or because the test lacks power by performing analyses similar to Chung and Kallpur (2003). Specifically, we evaluate the economic magnitude of an interquartile increase in our variable of interest at the upper 95 percent confidence interval. Because we estimate a binary outcome model, we first estimate the marginal effects holding all variables at their means for the logit regression estimated in Table 4. We find that at the upper 95 percent confidence interval (with a marginal effect of 0.036 for $\% M A S_{i t-1}$ ), an interquartile increase in $\% M A S_{i t-1}$ is estimated to increase the probability of misstatement by only 0.69 percent $(0.036 * 0.190)$; this is a 5.9 percent increase relative to the sample mean. ${ }^{29}$

To assess the economic magnitude of this impact, we contrast this result with the magnitude of an interquartile increase in other important predictors of misstatement and find that relative to these other predictors, the magnitude of the effect of $\% M A S_{i t-1}$ at the 95 percent confidence interval appears to be economically small. For instance, an interquartile increase in VarReturn would increase the probability of misstatement by 3.33 percent, which is a 28.7 percent increase relative to the sample mean (and approximately 4.8 times as large as the effect of an interqurtile increase in $\left.\% M A S_{i t-1}\right)$.

\footnotetext{
${ }^{29}$ We find similar results when estimating average marginal effects rather than marginal effects at the means.
} 
Finally, we examine the effect of an interquartile increase in $\% M A S_{i t-1}$ at the upper 95 percent confidence interval in the pre-SOX period. Here, we find that an interquartile increase in $\% M A S_{i t-1}$ is estimated to increase the probability of misstatement by 1.3 percent, which is approximately a 9 percent increase relative to the sample mean, and approximately 1.85 times as large as the effect in the post-SOX period. Based on these analyses, even at the upper end of the 95 percent confidence interval, the economic magnitude of any effect would be small in the postSOX period.

In addition, we employ a separate test to determine whether our sample size is large enough to detect an effect should one exist. To do this, we use the "power" function in STATA (the "power onemean" command). This test reveals that we would require a sample size of at least 18,817 observations to detect a one percent difference in the frequency of misstatement with 99 percent power. Moreover, our post-SOX sample size of 35,928 observations provides sufficient power to detect a change in the likelihood of misstatement as small as 0.73 percent. Because our tests are powerful enough to detect even an economically small effect on the likelihood of misstatement, we assert that our failure to reject the null hypothesis is unlikely to be due to low statistical power.

\section{Tests of Perceptions of Audit Quality}

Table 5 presents the results from our second hypotheses regarding investor perceptions of the quality of audited earnings. Panel A provides descriptive statistics for our sample of 27,124 company-year observations. Here, we find that cumulative abnormal returns (CARs) in the short window around the earnings announcement date average 0.3 percent. The average analyst forecast error is -0.8 percent, and descriptive statistics for other model variables are consistent with those from prior research.

[insert Table 5 here] 
Panel B reports the results from estimating equation (2) for the full sample, and for the pre- and post-SOX subsamples. The coefficient estimates on FERR are positive and significant (consistent with theory and with prior literature) for the full and pre-SOX samples. For the postSOX sample, the coefficient on FERR is not statistically significant at conventional levels ( $p=$ 0.125). Although the coefficient estimate on FERR*\%MAS is not statistically significant for the full sample, it is negative and significant for the pre-SOX sample $(p<0.05)$ but is not significantly different from zero for the post-SOX sample. Consistent with inferences from our prior restatement tests, we find that before SOX, investors perceived the quality of audited earnings to be lower when accounting firms generated more of their revenues from consulting, but this relation does not hold post-SOX. We also find that at the engagement-level, following SOX, the ratio of client-specific advisory and other fees to total public audit client fees (MAS_client) negatively impacts investor perceptions of audit quality (consistent with our misstatement tests).

To assess the insignificant association between \%MAS and short-window ERCs following SOX, we evaluate the economic magnitude of an interquartile increase in our variable of interest. We find that at the lower 95 percent confidence interval (-0.327), an interquartile increase in FERR*\%MAS it-1 is estimated to reduce CARs by only 0.00018 . We contrast this with the magnitude of an interquartile increase in another important predictor of CARs, namely the earnings surprise (FERR). An interquartile increase in FERR is estimated to increase CARs by 0.001, which is approximately 5.4 times as large in magnitude as the effect of an interquartile increase in FERR*\%MAS $S_{i t-1}$ at the lower 95 percent confidence interval. Based on this analysis, even at the lower end of the 95 percent confidence interval, the economic magnitude of any effect of \%MAS $S_{i t-1}$ in the post-SOX period would be small. 
We also use the "power” function in STATA determine whether our sample size is sufficient to detect an effect should one exist. In order to detect a change of just 0.5 percent in CARs (a small, arbitrarily chosen change) with 99 percent power, we would need only 6,228 observations, which we greatly exceed. In fact, our post-SOX sample size of 21,615 observations provides 99 percent power to detect a 0.24 percent difference (0.0024) in CARs. Because our tests are powerful enough to detect even an economically small effect on CARs, our failure to reject the null hypothesis in these tests is unlikely to be due to low statistical power.

\section{Additional Analyses}

In our main analyses, we focus on the level of consulting service revenue relative to total accounting firm revenue. We recognize that while the level of accounting firm consulting revenue may impact the social norms and culture of an accounting firm, changes in the amount of consulting service revenue generated by a firm may also play an important role. As such, we examine whether changes in accounting firms’ proportion of revenue generated from consulting services impact audit quality. To do this, we re-estimate equation (1) incorporating the change in $\% M A S$ between the one- and two-year lagged percentages. We present results from these tests in

panel A of Table 6. Similar to Table 4, we present the results using the full sample, the pre-SOX sample, and the post-SOX sample. Consistent with Column (2) in Table 4, we find a positive association between changes in the proportion of accounting firm revenue generated from consulting services and audit quality in the pre-SOX period. However, in the post-SOX period, we find a negative and significant association between changes in the proportion of accounting firm revenue generated from consulting services and audit quality.

[insert Table 6 here] 
We also examine whether the association between consulting revenues generated by accounting firms and impaired audit quality manifests only at certain thresholds. Social identity theory suggests that individuals are likely to adopt the mindset perceived as typical of the organization (Ashforth and Mael 1989). This theory does not specify the level of consulting revenues that might trigger a change in mindset or social norms, so we examine whether audit quality appears to suffer when accounting firms derive the majority of their revenues from consulting. To do this, we create an indicator variable set to one for observations where \%MAS is 50 percent or greater, and zero otherwise. ${ }^{30}$ We re-estimate equation (1) replacing \%MAS with this indicator variable and present summarized results in panel B. Here, we find that clients are more likely to misstate when their accounting firms derive the majority of their revenues from consulting services. However, when partitioning our sample on SOX, we find that this association exists only in the pre-SOX period, and there is no significant association post-SOX. Overall, this set of tests provides evidence suggesting that even after controlling for clientspecific independence concerns (i.e., non-tax, non-audit service fees at the client level), deriving the majority of revenues from consulting services at the audit firm level negatively impacted audit quality prior to SOX. However, we find no evidence to suggest that audit firms deriving the majority of their revenues from consulting services provide lower quality audits following SOX.

\section{Sensitivity Analyses}

We perform a number of untabulated sensitivity tests to ensure that our results are not driven by methodological choices. First, we note that non-reliance restatements, which are associated with an 8-K (Item 4.02) filing and/or an amended 10-K filing, are arguably more

\footnotetext{
${ }^{30}$ In untabulated analyses, we also examine whether an association between accounting firm consulting revenues and the likelihood of misstatement exists using lower thresholds (e.g., 10 percent, 25 percent, etc.) but find evidence of this relation only when accounting firms derive the majority of their revenues from consulting services.
} 
severe than the misstatements that we use in our primary tests (i.e., those identified through restatement announcements). We use all misstatements in our primary tests because Item 4.02 was added as an 8-K triggering event in August 2004 and as such, any misstatements associated with non-reliance restatements prior to that date would not be included in the analyses. However, to assess the sensitivity of our results, we limit our analyses to non-reliance restatements identified using a feature on the Audit Analytics website. We find that our inferences are robust to using this subset of misstatements. Specifically, we find a positive and significant likelihood of misstatement identified through non-reliance restatements when accounting firms derive a larger amount of revenue from consulting prior to SOX, but following SOX, we do not find a statistically significant relation.

Next, because the expansion of consulting service revenues has been driven by the largest accounting firms, we limit our analyses to clients of Big $\mathrm{N}$ auditors. With these more limited samples, we continue to find, consistent with our main tests presented in Tables 4 and 5, evidence of lower audit quality and perceptions of audit quality when audit firm consulting revenues are higher in the years before SOX but not after SOX.

Finally, because our primary analyses are at the client level and our measure of consulting influence is at the audit firm level, we examine the robustness of our results to collapsing the analysis to the audit firm level, where variables take on yearly averages for the respective audit firm. Performing this analysis for all 553 audit firm-years, we find a negative and significant coefficient on \%MAS over the full sample period, but the coefficient is insignificant in the pre-SOX period and negative and significant coefficient in the post-SOX period. We note, however, that there is a potential small audit firm bias because a small audit firm with only a few clients will have a large misstatement rate if even one client misstates. To 
alleviate this potential bias, we limit the analysis to larger audit firms (i.e., the Big $\mathrm{N}$ and second tier). Although the sample size is small (at 90 observations for the full sample period, including 23 pre-SOX and 67 post-SOX), while controlling for average public audit client non-tax nonaudit fees, average public audit client tax related fees, average public audit client size, average public audit client performance (ROA), and year fixed effects, we find a significantly higher audit firm-level misstatement rate when larger audit firms derive a larger proportion of revenues from consulting services prior to SOX. Following SOX, however, we do not find a statistically significant association between consulting revenues and misstatement rates. Assessing the insignificant post-SOX result, we find that even at the upper 95 percent confidence interval, the coefficient on \%MAS is smaller in magnitude than would be necessary to reject the null hypothesis at the ten percent level given the estimated standard errors.

\section{Conclusion}

Over the past decade, accounting firms have steadily increased the proportion of their revenues generated from consulting services, primarily by performing consulting services for nonaudit clients. Regulators and some academics have expressed concerns about the effect of this trend on the quality of audit services because they suggest that expanding the provision of consulting services can alter the firm's identity and shift social norms away from providing professional service to pleasing the client. In addition, an increased focus on profitability could shift resources away from the assurance practice. Accounting firms, however, argue that providing consulting services improves audit quality because consulting personnel often provide valuable insights to audit staff when they act as specialists on audit engagements.

We provide archival evidence on the relations between the proportion of accounting firm revenue generated from consulting services and restatements and perceptions of the quality of audited earnings. Our results suggest that before SOX, when audit clients provided an important 
source of consulting revenues, higher levels of accounting firm consulting revenues in the previous year increased the likelihood of misstatement and negatively impacted clients' annual ERCs, suggesting that higher levels of accounting firm consulting revenues negatively impacted audit quality and investor perceptions of audit quality. However, we find no evidence that these relations persist following SOX, and even if these relations do exist, the potential economic magnitude of the effect is small.

We recognize that our study is subject to data limitations. Specifically, our data for consulting service revenue is limited to the "Top 100 Firms" from Accounting Today. These data are only provided at the audit firm level and not at more disaggregated levels. Additionally, these fee data are provided from public, private, non-profit, and governmental clients, while other sources of data used in this study only cover publicly-traded audit clients. Despite this limitation, we believe the results of this study provide insights into the important question of the effect of accounting firms' expansion of consulting services on audit quality - a question that has received regulatory and academic attention, but has not yet been examined empirically. 


\section{References}

Advisory Committee on the Auditing Profession (ACAP). 2008. Final Report of the Advisory Committee on the Auditing Profession to The U.S. Department of the Treasury. Washington, DC: The Department of the Treasury.

Aobdia, D. 2017. The validity of publicly available measures of audit quality. Evidence from the PCAOB inspection data. Working paper, Public Company Accounting Oversight Board, Center for Economic Analysis and Northwestern University, doi:10.2139/ssrn.2629305.

Ashforth, B. E., and F. Mael. 1989. Social identity theory and the organization. Academy of Management Review 14 (1): 20-39.

Ashbaugh, H., R. LaFond, and B. W. Mayhew. 2003. Do nonaudit services compromise auditor independence? Further evidence. The Accounting Review 78 (3): 611-39.

Beardsley, E. L., D. R. Lassila, and T. C. Omer. 2016. How do audit firms respond to fee pressure? Evidence of increased nonaudit services and their impact on audit quality. Working Paper, Texas A\&M University and University of Nebraska-Lincoln, doi: 10.2139/ssrn.2433048.

Blankley, A. I., D. N. Hurtt, and J. E. Macgregor. 2012. Abnormal audit fees and restatements. Auditing: A Journal of Practice \& Theory 31 (1): 79-96.

Cao, Y., L. A. Myers, and T. C. Omer. 2012. Does company reputation matter for financial reporting quality? Evidence from restatements. Contemporary Accounting Research 29 (3): 95690 .

Christensen, B. E., S. M. Glover, T. C. Omer, and M. K. Shelley. 2016. Understanding audit quality: Insights from audit professionals and investors. Contemporary Accounting Research 33 (4): 1648-84.

Chung, H., and S. Kallapur. 2003. Client importance, nonaudit services, and abnormal accruals. The Accounting Review 78 (4): 931-55.

Dechow, P. M., R. G. Sloan, and A. P. Sweeney. 1995. Detecting earnings management. The Accounting Review 70 (2): 193-225.

Dechow, P. M., R. G. Sloan, and A. P. Sweeney. 1996. Causes and consequences of earnings manipulation: An analysis of firms subject to enforcement actions by the SEC. Contemporary Accounting Research 13 (1): 1-36.

DeFond, M. L., K. Raghunandan, and K. R. Subramanyam. 2002. Do non-audit service fees impair auditor independence? Evidence from going concern audit opinions. Journal of Accounting Research 40 (4): 1247-74.

Dey, R. M., A. Robin, and D. Tessoni. 2012. Advisory services rise again at large audit firms. The CPA Journal 82 (8): 58-67. 
Fischer, P., and S. Huddart. 2008. Optimal contracting with endogenous social norms. American Economic Review 98 (4): 1459-75.

Francis, J., and B. Ke. 2006. Disclosure of fees paid to auditors and the market valuation of earnings surprises. Review of Accounting Studies 11 (4): 495-523.

Francis, J., and P. N. Michas. 2013. The contagion effect of low-quality audits. The Accounting Review 88 (2): 521-52.

Francis, J., and M. D. Yu. 2009. Big 4 office size and audit quality. The Accounting Review 84 (5): 1521-52.

Frankel, R. M., M. F. Johnson, and K. K. Nelson. 2002. The relation between auditors' fees for nonaudit services and earnings management. The Accounting Review 77 (Supplement): 71-105.

Ghosh, A., S. Kallapur, and D. Moon. 2009. Audit and non-audit fees and capital market perceptions of auditor independence. Journal of Accounting and Public Policy 28 (5): 369-85.

Ghosh, A., and R. Pawlewicz. 2009. The impact of regulation on auditor fees: Evidence from the Sarbanes-Oxley Act. Auditing: A Journal of Practice \& Theory 28 (2): 171-97.

Goldwasser, D. L., and T. W. Morris. 2002. The accounting profession’s regulatory dilemma. The CPA Journal 72 (5): 8.

Hermanson, D. R. 2009. How consulting services could kill private-sector auditing. The CPA Journal 79 (1): 6-9.

Kennedy, P. 2008. A Guide to Econometrics, $6^{\text {th }}$ ed. Malden, MA: Blackwell Publishing.

Kinney, W. R., Z-V. Palmrose, and S. Scholz. 2004. Auditor independence, non-audit services, and restatements: Was the U.S. government right? Journal of Accounting Research 42 (3): 56188.

Koh, K., S. Rajgopal, and S. Srinivasan. 2013. Non-audit Services and financial reporting quality: Evidence from 1978 to 1980. Review of Accounting Studies 18 (1): 1-33.

Kothari, S. P., A. J. Leone, and C. E. Wasley. 2005. Performance matched discretionary accruals measures. Journal of Accounting and Economics 39 (1): 163-97.

Krishnan, J., L. Su, and Y. Zhang. 2011. Nonaudit services and earnings management in the preSOX and post-SOX eras. Auditing: A Journal of Practice and Theory 30 (3): 103-23.

Lennox, C. S. 2016. Did the PCAOB's restrictions on auditors' tax services improve audit quality? The Accounting Review 91 (5): 1493-512.

Livnat, J., and R. R. Mendenhall. 2006. Comparing the post-earnings announcement drift for surprises calculated from analyst and time series forecasts. Journal of Accounting Research 44 (1): 177-205. 
Lobo, G. J., and Y. Zhao. 2013. Relation between audit effort and financial report misstatements: Evidence from quarterly and annual restatements. The Accounting Review 88 (4): 1385-412.

Nam, S., and J. Ronen. 2012. The impact of nonaudit services on capital markets. Journal of Accounting, Auditing \& Finance 27 (1): 32-60.

Panel on Audit Effectiveness. 2000. The Panel on Audit Effectiveness: Report and Recommendations. New York: Public Oversight Board of the American Institute of Certified Public Accountants.

Paterson, J. S., and A. Valencia. 2011. The effects of recurring and nonrecurring tax, auditrelated, and other nonaudit services on auditor independence. Contemporary Accounting Research 28 (5): 1510-36.

Public Company Accounting Oversight Board (PCAOB). 2003. Reports on Audited Financial Statements: Interim Standard AU 508. Washington, D.C.: PCAOB.

Reichelt, K. J., and D. Wang. 2010. National and office-specific measures of auditor industry expertise and effects on audit quality. Journal of Accounting Research 48 (3): 647-86.

Schmidt, J. J. 2012. Perceived auditor independence and audit litigation: The role of nonaudit services fees. The Accounting Review 87 (3): 1033-65.

Simunic, D. A. 1984. Auditing, consulting, and auditor independence. Journal of Accounting Research 22 (2): 679-702.

Stanley, J. D., and F. T. DeZoort. 2007. Audit firm tenure and financial restatements: An analysis of industry specialization and fee effects. Journal of Accounting and Public Policy 26 (2): 131-59.

Summers, S. L., and J. T. Sweeney. 1998. Fraudulently misstated financial statements and insider trading: An empirical analysis. The Accounting Review 73 (1): 131-46.

Teoh, S. H., and T. J. Wong. 1993. Perceived auditor quality and the earnings response coefficient. The Accounting Review 68 (2): 346-66.

United States Code, Sarbanes-Oxley Act of 2002, PL 107-204, 116 Stat 745, Codified in Sections 11, 15, 18, 28, and 29 USC, July 2002.

Wyatt, A. R. 2004. Accounting professionalism - They just don’t get it! Accounting Horizons 18 (1): 45-53. 
APPENDIX

Variable definitions

\begin{tabular}{|c|c|}
\hline Variable & Definition \\
\hline$\% M A S$ & $\begin{array}{l}\text { The proportion of U.S. management advisory and other fees (i.e., } \\
\text { consulting revenues) to total U.S. revenue, calculated at the } \\
\text { accounting-firm level as (MAS + Other fees) / (Audit + Tax + MAS } \\
\text { + Other fees) from Accounting Today }\end{array}$ \\
\hline$\triangle \% M A S$ & $\begin{array}{l}\text { The change in MAS at the accounting firm level between the one } \\
\text { and two year lagged percentages }\end{array}$ \\
\hline absFERR & $\begin{array}{l}\text { The absolute value of FERR, where FERR is analyst forecast error } \\
\text { measured as the difference between reported annual earnings per } \\
\text { share and the most recent median consensus analyst forecast (per } \\
I / B / E / S \text { ) deflated by stock price at the end of the fiscal year } \\
\text { (Compustat variable PRCC_F) }\end{array}$ \\
\hline ARINV & $\begin{array}{l}\text { The sum of accounts receivable and inventory (Compustat variables } \\
\text { RECT and INVT) divided by total assets (Compustat variable AT) }\end{array}$ \\
\hline$B i g N$ & $\begin{array}{l}\text { An indicator variable set equal to one if the auditor is from the Big } \\
4 \text { (or Arthur Andersen LLP), and zero otherwise (identified with } \\
\text { Audit Analytics variable AUDITOR_FKEY) }\end{array}$ \\
\hline$C A R$ & $\begin{array}{l}\text { Abnormal (market-adjusted) returns cumulated over days }[-1,+1] \\
\text { relative to the annual earnings announcement }\end{array}$ \\
\hline ClientImport & $\begin{array}{l}\text { The ratio of total fees received from the client to the total fees } \\
\text { received from all of the audit firm's public audit clients }\end{array}$ \\
\hline$D E$ & $\begin{array}{l}\text { The ratio of short- and long-term debt (Compustat variables DLC } \\
\text { and DLTT) to total equity (Compustat variable SEQ) }\end{array}$ \\
\hline FERR & $\begin{array}{l}\text { Analyst forecast error measured as the difference between reported } \\
\text { annual earnings per share and the most recent median consensus } \\
\text { analyst forecast (per } I / B / E / S \text { ) deflated by stock price at the end of } \\
\text { the fiscal year (Compustat variable PRCC_F) }\end{array}$ \\
\hline FIN & $\begin{array}{l}\text { The sum of cash raised from the issuance of long-term debt, } \\
\text { common stock, and preferred stock (Compustat variables DLTIS } \\
\text { and SSTK) divided by total assets (Compustat variable AT) }\end{array}$ \\
\hline FREEC & $\begin{array}{l}\text { Cash from operations minus average capital expenditures } \\
\text { (Compustat variables OANCF and CAPX) divided by lagged total } \\
\text { assets (Compustat variable AT) }\end{array}$ \\
\hline ICMW & $\begin{array}{l}\text { An indicator variable set equal to one if a material weakness in } \\
\text { internal controls over financial reporting is disclosed in the year, } \\
\text { and zero otherwise }\end{array}$ \\
\hline
\end{tabular}


Industry FE Industry fixed effects using SIC codes to define industries as follows (Ashbaugh et al. 2003): agriculture (0100-0999), mining and construction (1000-1999, excluding 1300-1399), food (20002111), textiles and printing/publishing (2200-2799), chemicals (2800-2824; 2840-2899), pharmaceuticals (2830-2836), extractive (1300-1399; 2900-2999), durable manufacturers (3000-3999, excluding 3570-3579 and 3670-3679), transportation (4000-4899), retail (5000-5999), services (7000-8999, excluding 7370-7379), computers (3570-3579; 3670-3679; 7370-7379), and utilities (49004999)

Leverage Long-term debt plus the current portion of long-term debt (Compustat variables DLC and DLTT) divided by total assets (Compustat variable AT)

LnAFEE The natural log of audit and audit-related fees (from AuditAnalytics)

LnAssets The natural log of total assets (Compustat variable AT)

LnMV

Loss

$M \& A$

MAS_client

Misstate

MTB

OffSize

Restructure An indicator variable set equal to one if special items (Compustat variable SPI) as a percentage of total assets (Compustat variable AT) is less than or equal to $-5 \%$, and zero otherwise

$R O A$ 
SecondTier An indicator variable set equal to one if the new auditor is from the second tier (BDO Seidman, Grant Thornton, and McGladrey \& Pullen), and zero otherwise (identified with Audit Analytics variable AUDITOR_FKEY)

Specialist An indicator variable set equal to one if the auditor is an industry specialist, defined following Reichelt and Wang (2010) as an auditor whose audit fee market share in the 2-digit SIC code exceeds 30 percent at the national level, and zero otherwise

SQRTTenure The square root of auditor tenure, where tenure is measured as the number of consecutive years of the auditor-client relationship to date

STD_Return The standard deviation of market-adjusted buy-and-hold returns (where market-adjusted returns are the difference between raw returns and the value-weighted market returns from CRSP) over the previous 60 months

Tax_client Client-level tax fees paid to the auditor divided by the total client fees paid to the auditor (from Audit Analytics)

VarReturn The standard deviation of market-adjusted buy-and-hold returns (where market-adjusted returns are the difference between the raw returns and the value-weighted market returns from CRSP) over the previous 12 months

Year FE Year fixed effects 
Figure 1 Revenues from Audit and Assurance (A\&A), Tax, and Management Advisory Services (MAS) as a Percentage of Total U.S. Revenue for the Accounting Today Top 100 Firms (2000 - 2015)

Data source: Accounting Today

$60.0 \%$

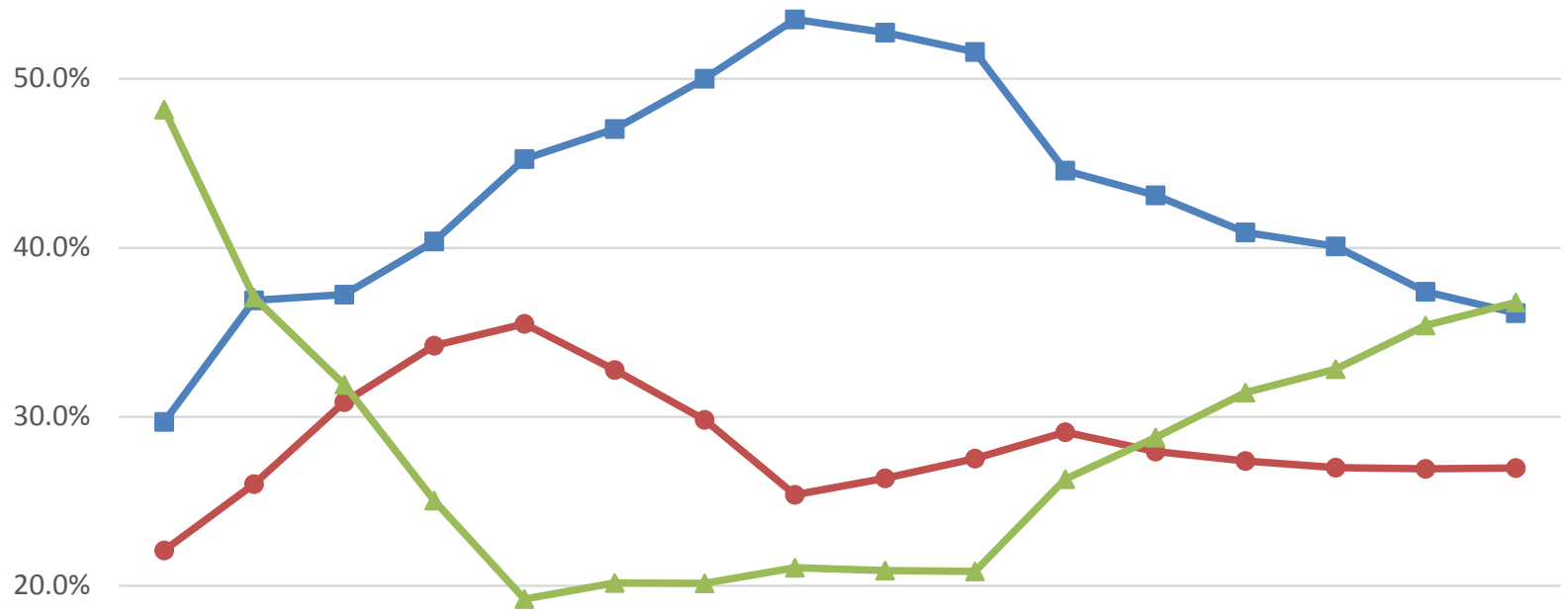

$10.0 \%$

$0.0 \%$

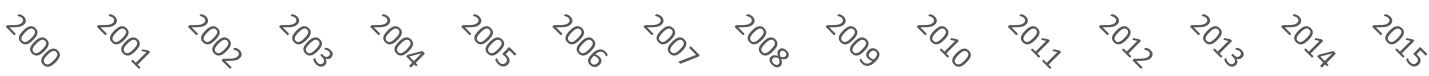

$$
\begin{aligned}
& -\mathrm{A} \& \mathrm{~A} \%-\mathrm{Tax} \% \longrightarrow \mathrm{MAS} \%
\end{aligned}
$$


Figure 2 Non-Audit, Non-Tax Related Public Audit Client Fees (MAS_client) as a Percentage of Total Public Audit Client Fees for Sample (2000 - 2013)

Data source: Audit Analytics

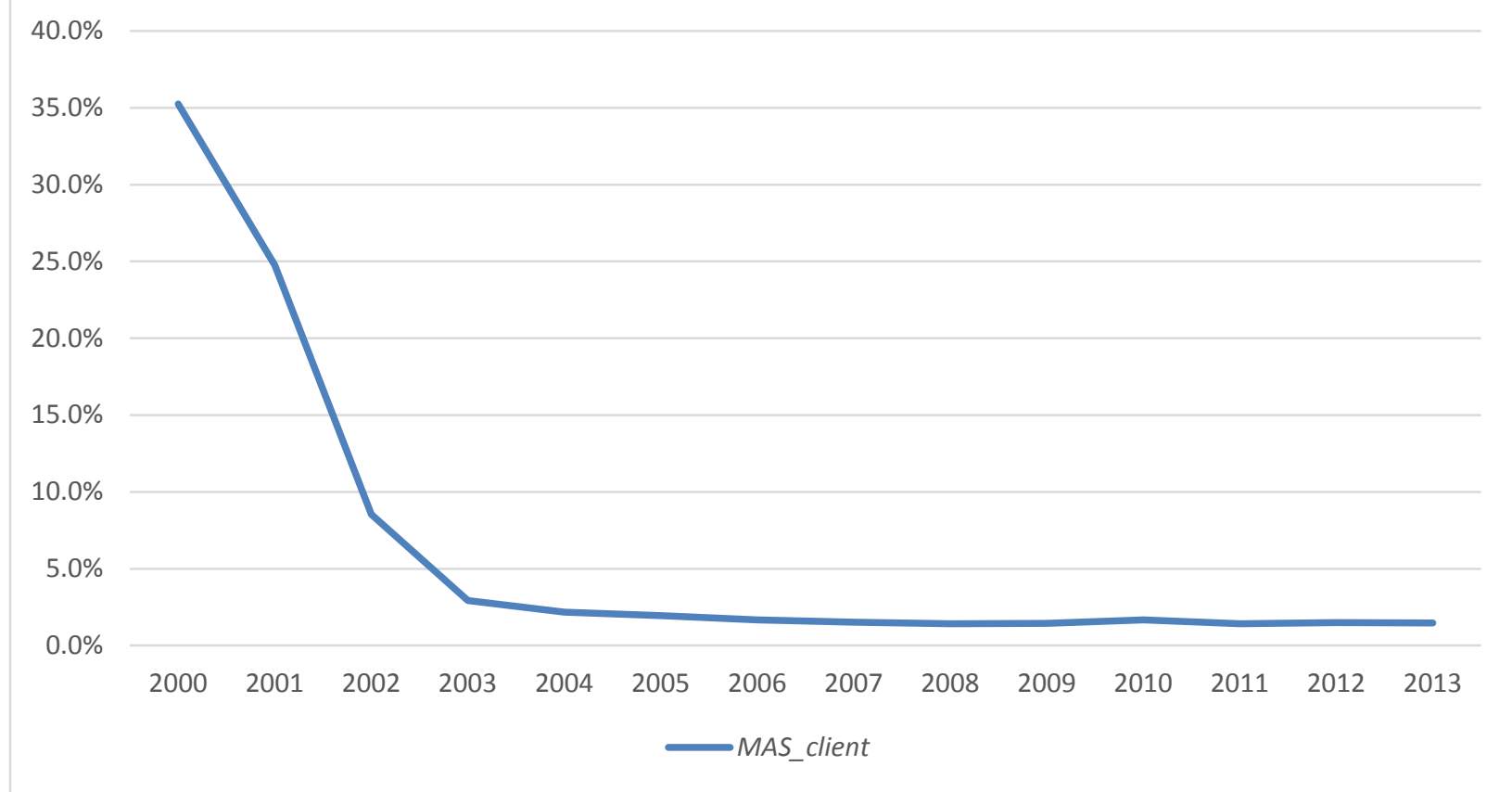


TABLE 1

Sample selection

$\mathbf{N}$

Observations with a fiscal year end between 2000 and 2013, inclusive, after merging with Compustat, CRSP, and Audit Analytics

84,177

Less: KPMG clients during 2005, 2006 and 2007 with missing $\% M A S_{i t-1}$ data

Less: observations with missing data to construct model variables

Less: observations where the signing auditor office is outside the U.S.

Less: observations with missing 1-year lagged \%MAS

Misstatement sample

46,864

\section{Short-window market reaction tests}

Observations of firm-years from the sample above with available data after merging with Compustat, CRSP, I/B/E/S, and Audit Analytics

27,421

Less: observations with stock price less than $\$ 1$ at the end of the fiscal year

Short-window market reaction sample 


\section{TABLE 2}

Descriptive statistics

Panel A: Fee-related variables

This panel reports the descriptive statistics for fee-related variables for the company-year observations in our sample from 2000 through 2013 (full sample), and then separately from 2000 through 2002 (pre-SOX sample) and 2003 through 2013 (post-SOX sample). See the Appendix for variable definitions.

Full sample (2000 through 2013)

\begin{tabular}{lcccccccc}
\hline Variable & $\mathbf{N}$ & Mean & Std & Min & P25 & Median & P75 & Max \\
\hline \%MAS jt-1 $_{\text {MAS_client }}$ & 46,864 & 0.258 & 0.175 & 0.010 & 0.120 & 0.260 & 0.430 & 0.720 \\
Tax_client $_{i t}$ & 46,864 & 0.071 & 0.167 & 0.000 & 0.000 & 0.000 & 0.022 & 0.980 \\
& 46,864 & 0.098 & 0.128 & 0.000 & 0.000 & 0.046 & 0.151 & 0.873 \\
\hline
\end{tabular}

Pre-SOX sample (2000 through 2002)

\begin{tabular}{lcccccccc}
\hline Variable & $\mathbf{N}$ & Mean & Std & Min & P25 & Median & P75 & Max \\
\hline \%MAS $j$ t-1 & 10,936 & 0.437 & 0.167 & 0.040 & 0.430 & 0.450 & 0.500 & 0.720 \\
MAS_client $_{i t}$ & 10,936 & 0.259 & 0.255 & 0.000 & 0.000 & 0.201 & 0.455 & 0.980 \\
Tax_client $_{i t}$ & 10,936 & 0.097 & 0.163 & 0.000 & 0.000 & 0.000 & 0.160 & 0.873 \\
\hline
\end{tabular}

Post-SOX sample (2003 through 2013)

\begin{tabular}{|c|c|c|c|c|c|c|c|c|}
\hline Variable & $\mathbf{N}$ & Mean & Std & Min & P25 & Median & P75 & Max \\
\hline$\% M A S_{j t-1}$ & 35,924 & 0.204 & 0.138 & 0.000 & 0.100 & 0.190 & 0.290 & 0.530 \\
\hline MAS_client & 35,924 & 0.014 & 0.052 & 0.000 & 0.000 & 0.000 & 0.002 & 0.864 \\
\hline Tax_client $_{i t}$ & 35,924 & 0.098 & 0.115 & 0.000 & 0.000 & 0.059 & 0.150 & 0.818 \\
\hline
\end{tabular}


Panel B: Other variables

This panel reports the descriptive statistics for other model variables. See the Appendix for variable definitions.

\begin{tabular}{|c|c|c|c|c|c|c|}
\hline Variable & $\mathbf{N}$ & Mean & Std & P25 & Median & P75 \\
\hline Misstate $_{i t}$ & 46,864 & 0.124 & 0.329 & 0.000 & 0.000 & 0.000 \\
\hline $\operatorname{LnAFEE}_{i t}$ & 46,864 & 13.529 & 1.316 & 12.567 & 13.518 & 14.366 \\
\hline$B i g N$ & 46,864 & 0.820 & 0.384 & 1.000 & 1.000 & 1.000 \\
\hline SecondTier & 46,864 & 0.102 & 0.303 & 0.000 & 0.000 & 0.000 \\
\hline Specialist $_{i t}$ & 46,864 & 0.230 & 0.421 & 0.000 & 0.000 & 0.000 \\
\hline SQRTTenure $_{i t}$ & 46,864 & 2.327 & 0.903 & 1.732 & 2.236 & 3.000 \\
\hline$I C M W_{i t}$ & 46,864 & 0.037 & 0.190 & 0.000 & 0.000 & 0.000 \\
\hline LnAssets $_{i t}$ & 46,864 & 6.361 & 2.060 & 4.911 & 6.328 & 7.738 \\
\hline Leverage $_{i t}$ & 46,864 & 0.226 & 0.259 & 0.018 & 0.164 & 0.349 \\
\hline$M T B_{i t}$ & 46,864 & 2.651 & 5.543 & 1.083 & 1.808 & 3.155 \\
\hline$F I N_{i t}$ & 46,864 & 0.165 & 0.321 & 0.006 & 0.039 & 0.183 \\
\hline$F_{R E E C_{i t}}$ & 46,864 & 0.089 & 0.292 & 0.022 & 0.104 & 0.190 \\
\hline$M \& A_{i t}$ & 46,864 & 0.117 & 0.322 & 0.000 & 0.000 & 0.000 \\
\hline$R O A_{i t}$ & 46,864 & -0.053 & 0.409 & -0.026 & 0.022 & 0.064 \\
\hline Loss $_{i t}$ & 46,864 & 0.326 & 0.469 & 0.000 & 0.000 & 1.000 \\
\hline$A R I N V_{i t}$ & 46,864 & 0.270 & 0.221 & 0.088 & 0.220 & 0.397 \\
\hline VarReturn $_{i t}$ & 46,864 & 0.044 & 0.017 & 0.026 & 0.050 & 0.057 \\
\hline OffSize $_{i t}$ & 46,864 & 17.221 & 1.700 & 16.127 & 17.540 & 18.475 \\
\hline
\end{tabular}

All variables are defined in the Appendix. 
TABLE 3

Correlations

\begin{tabular}{|c|c|c|c|c|c|c|c|c|c|c|c|}
\hline Variable & (1) & (2) & (3) & (4) & (5) & (6) & $(7)$ & $(8)$ & (9) & $(10)$ & $(11)$ \\
\hline (1) Misstate $_{i t}$ & & 0.05 & 0.03 & 0.03 & 0.04 & 0.06 & -0.02 & 0.03 & -0.02 & 0.09 & 0.03 \\
\hline (2) $\% M A S_{j t-1}$ & 0.05 & & 0.45 & -0.01 & -0.23 & 0.14 & -0.12 & -0.05 & -0.24 & -0.06 & -0.07 \\
\hline (3) $M A S \_c l i e n t$ it & 0.04 & 0.30 & & -0.22 & -0.28 & 0.09 & -0.07 & 0.00 & -0.30 & -0.07 & -0.08 \\
\hline (4) Tax_client $i t$ & 0.02 & -0.11 & -0.22 & & 0.04 & 0.09 & -0.07 & 0.04 & 0.02 & -0.04 & 0.07 \\
\hline (5) $L n \overline{A F E} E_{i t}$ & 0.04 & -0.22 & -0.14 & 0.16 & & 0.34 & -0.18 & 0.18 & 0.35 & 0.08 & 0.77 \\
\hline (6) $B i g N_{i t}$ & 0.06 & 0.13 & 0.12 & 0.08 & 0.36 & & -0.72 & 0.26 & 0.20 & -0.07 & 0.31 \\
\hline (7) SecondTier & -0.02 & -0.11 & -0.11 & -0.08 & -0.19 & -0.72 & & -0.18 & -0.14 & 0.04 & -0.23 \\
\hline (8) Specialist $_{i t}$ & 0.03 & -0.04 & 0.04 & 0.06 & 0.18 & 0.26 & -0.18 & & 0.08 & -0.01 & 0.16 \\
\hline (9) SQRTTenure ${ }_{i t}$ & -0.02 & -0.25 & -0.23 & 0.13 & 0.39 & 0.19 & -0.13 & 0.08 & & -0.01 & 0.27 \\
\hline$(10) I C M W_{i t}$ & 0.09 & -0.06 & -0.06 & -0.02 & 0.08 & -0.07 & 0.04 & -0.01 & -0.01 & & -0.03 \\
\hline (11)LnAssets $i t$ & 0.03 & -0.07 & -0.01 & 0.14 & 0.75 & 0.30 & -0.23 & 0.16 & 0.29 & -0.03 & \\
\hline (12)Leverage & 0.04 & 0.04 & 0.01 & 0.03 & 0.22 & 0.10 & -0.06 & $\mathbf{0 . 0 7}$ & 0.01 & -0.01 & 0.35 \\
\hline (13)MTB $B_{i t}$ & -0.01 & -0.05 & -0.02 & $\mathbf{0 . 0 7}$ & 0.11 & 0.11 & -0.05 & 0.04 & 0.04 & -0.02 & 0.00 \\
\hline$(14) F I N_{i t}$ & 0.02 & 0.02 & 0.02 & -0.01 & 0.07 & 0.07 & -0.03 & 0.02 & -0.06 & -0.01 & 0.03 \\
\hline (15)FREEC $C_{i t}$ & 0.03 & 0.00 & 0.00 & $\mathbf{0 . 0 7}$ & 0.20 & 0.14 & -0.04 & 0.08 & 0.07 & -0.04 & 0.19 \\
\hline$(16) M \& A_{i t}$ & 0.01 & -0.02 & -0.04 & 0.04 & 0.24 & 0.04 & -0.03 & 0.01 & 0.18 & 0.01 & 0.18 \\
\hline$(17) R O A_{i t}$ & -0.01 & -0.04 & -0.02 & 0.11 & 0.20 & 0.10 & -0.04 & $\mathbf{0 . 0 7}$ & 0.13 & -0.06 & 0.26 \\
\hline (18)Loss $i t$ & 0.00 & 0.04 & 0.03 & -0.10 & -0.20 & -0.06 & 0.05 & -0.05 & -0.13 & 0.06 & -0.36 \\
\hline (19)ARINV $V_{i t}$ & -0.01 & 0.01 & 0.00 & 0.02 & -0.06 & -0.21 & 0.09 & -0.06 & -0.02 & 0.02 & -0.05 \\
\hline (20)VarReturn & 0.01 & 0.21 & 0.18 & -0.08 & -0.15 & 0.06 & -0.05 & -0.01 & -0.10 & -0.10 & -0.04 \\
\hline (21)OffSize ${ }_{i t}$ & 0.04 & -0.06 & 0.00 & 0.10 & 0.44 & 0.58 & -0.37 & 0.22 & 0.22 & -0.01 & 0.29 \\
\hline
\end{tabular}

Bolded correlations are significant at 0.05. Pearson correlations are above the diagonal and Spearman correlations are below the diagonal. All variables are defined in the Appendix. $\mathrm{N}=46,864$. 
TABLE 3 cont'd

Correlations

\begin{tabular}{|c|c|c|c|c|c|c|c|c|c|c|}
\hline Variable & (12) & (13) & (14) & (15) & (16) & $(17)$ & (18) & (19) & (20) & (21) \\
\hline (1) Misstate $_{i t}$ & 0.03 & -0.01 & 0.00 & 0.03 & 0.01 & 0.02 & 0.00 & -0.02 & 0.01 & 0.04 \\
\hline (2) $\% M A S_{j t-1}$ & 0.03 & -0.01 & 0.01 & -0.01 & -0.03 & -0.04 & 0.05 & 0.00 & 0.24 & -0.05 \\
\hline (3) $M A S \_c l i e n t_{i t}$ & 0.01 & 0.00 & 0.04 & -0.02 & -0.09 & -0.04 & 0.06 & -0.02 & 0.25 & -0.06 \\
\hline (4) Tax_client ${ }_{i t}$ & 0.02 & 0.01 & -0.05 & 0.06 & 0.00 & 0.06 & -0.08 & -0.01 & -0.01 & 0.06 \\
\hline (5) $L n A F E E_{i t}$ & 0.13 & 0.00 & -0.06 & 0.15 & 0.23 & 0.16 & -0.20 & -0.11 & -0.15 & 0.46 \\
\hline (6) $B i g N_{i t}$ & 0.08 & 0.02 & -0.01 & 0.07 & 0.04 & 0.05 & -0.06 & -0.25 & 0.06 & 0.63 \\
\hline (7) SecondTier it & -0.04 & -0.01 & 0.01 & -0.02 & -0.03 & -0.01 & 0.05 & 0.10 & -0.04 & -0.36 \\
\hline (8) Specialist $_{i t}$ & 0.04 & 0.01 & -0.02 & 0.04 & 0.01 & 0.04 & -0.05 & -0.08 & -0.01 & 0.23 \\
\hline (9) SQRTTenure $i t$ & -0.01 & 0.00 & -0.07 & 0.05 & 0.17 & 0.08 & -0.12 & -0.04 & -0.08 & 0.21 \\
\hline (10) $I C M W_{i t}$ & 0.00 & -0.01 & 0.00 & -0.01 & 0.01 & -0.03 & 0.06 & 0.02 & -0.10 & -0.01 \\
\hline (11)LnAssets & 0.18 & -0.05 & -0.12 & 0.23 & 0.18 & 0.30 & -0.35 & -0.04 & -0.05 & 0.32 \\
\hline (12)Leverage & & -0.09 & 0.20 & -0.01 & 0.00 & -0.11 & 0.05 & -0.10 & 0.02 & 0.04 \\
\hline (13)MTB & -0.15 & & 0.04 & 0.01 & 0.00 & 0.00 & -0.01 & -0.08 & -0.06 & 0.04 \\
\hline$(14) F I N_{i t}$ & 0.33 & 0.17 & & -0.27 & -0.01 & -0.23 & 0.13 & -0.05 & -0.04 & -0.02 \\
\hline (15)FREEC $C_{i t}$ & 0.02 & 0.26 & 0.00 & & 0.04 & 0.45 & -0.37 & 0.00 & 0.00 & 0.04 \\
\hline$(16) M \& A_{i t}$ & 0.03 & 0.03 & 0.03 & 0.04 & & 0.05 & -0.06 & -0.02 & -0.03 & 0.07 \\
\hline$(17) R O A_{i t}$ & -0.07 & 0.30 & -0.09 & 0.66 & 0.03 & & -0.40 & 0.10 & -0.06 & 0.04 \\
\hline (18)Loss $i t$ & -0.03 & -0.15 & 0.08 & -0.47 & -0.06 & -0.79 & & -0.12 & 0.12 & -0.04 \\
\hline (19)ARINV & -0.09 & -0.14 & -0.17 & -0.07 & 0.00 & 0.11 & -0.13 & & -0.01 & -0.24 \\
\hline (20)VarReturn & 0.03 & -0.19 & -0.08 & -0.02 & -0.03 & -0.10 & 0.12 & -0.02 & & -0.06 \\
\hline (21)OffSize $e_{i t}$ & 0.03 & 0.12 & 0.04 & 0.07 & 0.07 & 0.07 & -0.04 & -0.18 & -0.06 & \\
\hline
\end{tabular}

Bolded correlations are significant at 0.05. Pearson correlations are above the diagonal and Spearman correlations are below the diagonal. All

variables are defined in the Appendix. N=46,864. 
TABLE 4

The effect of accounting firm consulting revenue on audit quality

\begin{tabular}{|c|c|c|c|c|c|c|c|}
\hline \multirow[b]{2}{*}{ Variable } & \multirow[b]{2}{*}{ Pred. } & \multicolumn{2}{|c|}{ DV $=$ Misstate } & \multicolumn{2}{|c|}{$\begin{array}{c}(2) \\
\text { Pre-SOX } \\
(2000-2002) \\
\text { DV = Misstate }\end{array}$} & \multicolumn{2}{|c|}{$\begin{array}{c}\text { (3) } \\
\text { Post-SOX } \\
(2003-2013) \\
\text { DV = Misstate }\end{array}$} \\
\hline & & Coeff. Est. & z-statistic & Coeff. Est. & z-statistic & Coeff. Est. & z-statistic \\
\hline Intercept & ? & $-5.639 * * *$ & -13.720 & $-6.521 * * *$ & -7.200 & $-5.113^{* * *}$ & -10.420 \\
\hline$\% M A S_{j t-1}$ & $?$ & $0.389 * * *$ & 2.890 & $1.178 * * *$ & 5.500 & 0.031 & 0.170 \\
\hline MAS_client ${ }_{i t}$ & ? & $0.453 * * *$ & 3.160 & 0.254 & 1.520 & $0.623 *$ & 1.780 \\
\hline Tax_client $_{i t}$ & $?$ & 0.139 & 0.890 & -0.018 & -0.080 & 0.135 & 0.690 \\
\hline $\operatorname{Ln} \overline{A F E} E_{i t}$ & $?$ & $0.146^{* * *}$ & 3.990 & 0.094 & 1.550 & $0.163^{* * *}$ & 3.940 \\
\hline$B i g N_{i t}$ & $?$ & $0.486^{* * *}$ & 3.630 & $1.430 * * *$ & 2.790 & $0.531^{* * *}$ & 3.720 \\
\hline SecondTier $_{i t}$ & ? & $0.479 * * *$ & 3.500 & $1.755^{* * *}$ & 3.340 & $0.437 * * *$ & 3.100 \\
\hline Specialist $_{i t}$ & $?$ & $0.111^{* *}$ & 2.120 & -0.016 & -0.190 & $0.138 * *$ & 2.360 \\
\hline SQRTTenure $_{i t}$ & $?$ & 0.001 & 0.040 & 0.056 & 1.030 & -0.006 & -0.180 \\
\hline$I C M W_{i t}$ & + & $1.238 * * *$ & 18.610 & & & $1.220 * * *$ & 18.340 \\
\hline LnAssets $_{\text {it }}$ & $?$ & -0.019 & -0.840 & $0.068 *$ & 1.680 & $-0.048 *$ & -1.880 \\
\hline Leverage $_{i t}$ & + & $0.277 * * *$ & 3.210 & 0.174 & 1.160 & $0.310 * * *$ & 3.200 \\
\hline$M T B_{i t}$ & $?$ & -0.005 & -1.590 & -0.004 & -0.580 & $-0.005^{*}$ & -1.650 \\
\hline$F I N_{i t}$ & + & $0.085 *$ & 1.390 & 0.067 & 0.600 & $0.093 *$ & 1.320 \\
\hline$F_{R E E C_{i t}}$ & $?$ & 0.114 & 1.210 & $0.534 * * *$ & 3.000 & -0.045 & -0.480 \\
\hline$M \& A_{i t}$ & + & $0.119 * *$ & 2.050 & 0.177 & 1.110 & $0.102^{* *}$ & 1.660 \\
\hline$R O A_{i t}$ & $?$ & $0.205^{* * *}$ & 2.820 & 0.114 & 1.380 & $0.229 * *$ & 2.150 \\
\hline $\operatorname{Loss}_{i t}$ & + & $0.102^{* *}$ & 2.130 & $0.142 * *$ & 1.780 & $0.090 *$ & 1.620 \\
\hline$A R I N V_{i t}$ & + & 0.033 & 0.260 & $0.332 *$ & 1.500 & -0.086 & -0.600 \\
\hline VarReturn $_{i t}$ & + & $7.990 * * *$ & 4.060 & -12.836 & -1.760 & $11.660 * * *$ & 5.110 \\
\hline OffSize $_{i t}$ & $?$ & 0.021 & 1.110 & $0.053 *$ & 1.960 & -0.001 & -0.050 \\
\hline Industry FE & & Included & & Included & & Included & \\
\hline Year FE & & Included & & Included & & Included & \\
\hline $\mathrm{N}$ & & 46,864 & & 10,936 & & 35,928 & \\
\hline Area under ROC curve & & 0.662 & & 0.680 & & 0.664 & \\
\hline
\end{tabular}

This table reports the relation between Accounting Today’s Top 100 accounting firms' provision of consulting services and the likelihood of client non-reliance misstatements from 2000 through 2013 and broken out between pre-SOX (2000 through 2002) and post-SOX (2003 through 2013) periods. *, **, and ***

represent significance levels of 10 percent, 5 percent, and 1 percent, respectively, based on two-tailed tests, unless a direction is predicted. See the Appendix for variable definitions. 
TABLE 5

Earnings response coefficients

\begin{tabular}{|c|c|c|c|c|c|c|}
\hline \multicolumn{7}{|c|}{ Panel A: Descriptive statistics } \\
\hline Variable & $\mathbf{N}$ & Mean & Std & $\mathbf{P} 25$ & Median & P75 \\
\hline$C A R$ & 27,124 & 0.003 & 0.093 & -0.039 & 0.002 & 0.045 \\
\hline FERR & 27,124 & -0.008 & 0.334 & -0.001 & 0.000 & 0.002 \\
\hline$\% M A S_{j t-1}$ & 27,124 & 0.254 & 0.177 & 0.110 & 0.260 & 0.430 \\
\hline MAS_client & 27,124 & 0.067 & 0.165 & 0.000 & 0.000 & 0.013 \\
\hline Tax_client $_{\text {it- } 1}$ & 27,124 & 0.103 & 0.131 & 0.000 & 0.051 & 0.162 \\
\hline absFERR & 27,124 & 0.017 & 0.333 & 0.001 & 0.002 & 0.007 \\
\hline Loss $_{i t}$ & 27,124 & 0.276 & 0.447 & 0.000 & 0.000 & 1.000 \\
\hline Restructure $_{i t}$ & 27,124 & 0.170 & 0.375 & 0.000 & 0.000 & 0.000 \\
\hline$D E_{i t}$ & 27,124 & 0.674 & 1.904 & 0.005 & 0.314 & 0.878 \\
\hline$L n M V_{i t-1}$ & 27,124 & 6.647 & 1.761 & 5.413 & 6.535 & 7.743 \\
\hline$S T D \_R e t u r n ~ t-1$ & 27,124 & 0.044 & 0.017 & 0.027 & 0.044 & 0.057 \\
\hline Specialist $_{i t}$ & 27,124 & 0.272 & 0.445 & 0.000 & 0.000 & 1.000 \\
\hline OffSize $_{i t}$ & 27,124 & 17.488 & 1.456 & 16.565 & 17.710 & 18.585 \\
\hline ClientImport $_{i t}$ & 27,124 & 0.003 & 0.026 & 0.000 & 0.000 & 0.001 \\
\hline
\end{tabular}


Panel B: Regression analysis

\begin{tabular}{|c|c|c|c|c|c|c|c|}
\hline \multirow[b]{2}{*}{ Variable } & \multirow[b]{2}{*}{ Pred. } & \multicolumn{2}{|c|}{$\mathrm{DV}=C A R$} & \multicolumn{2}{|c|}{$\begin{array}{c}(2) \\
\text { Pre-SOX } \\
(2000-2002) \\
\text { DV = CAR }\end{array}$} & \multicolumn{2}{|c|}{$\begin{array}{c}(3) \\
\text { Post-SOX } \\
(2003-2013) \\
\text { DV }=\text { CAR }\end{array}$} \\
\hline & & Coeff. Est. & t-statistic & Coeff. Est. & t-statistic & Coeff. Est. & t-statistic \\
\hline Intercept & $?$ & $0.018^{*}$ & 1.910 & $0.057 * * *$ & 2.850 & 0.001 & 0.130 \\
\hline FERR & + & $0.303^{*}$ & 1.620 & $0.625^{*}$ & 1.480 & 0.249 & 1.150 \\
\hline$\% M A S_{j t-1}$ & $?$ & $-0.011 * *$ & -2.420 & 0.008 & 0.930 & $-0.017 * * *$ & -3.300 \\
\hline$F E R R \times \% M A S_{j t-1}$ & $?$ & -0.067 & -0.560 & $-0.353^{* *}$ & -2.310 & -0.007 & -0.050 \\
\hline MAS_client ${ }_{i t-1}$ & $?$ & -0.005 & -0.870 & -0.004 & -0.610 & $-0.025 *$ & -1.920 \\
\hline Tax_client $_{i t-1}$ & $?$ & 0.004 & 0.880 & 0.001 & 0.090 & 0.005 & 0.890 \\
\hline absFERR & $?$ & $0.040 * *$ & 1.960 & $0.092 *$ & 1.870 & $0.040 *$ & 1.860 \\
\hline LosS $_{i t}$ & ? & $-0.007 * * *$ & -3.760 & $-0.008 * *$ & -2.170 & $-0.006 * * *$ & -2.990 \\
\hline Restructure $_{i t}$ & ? & -0.001 & -0.330 & 0.004 & 0.990 & -0.002 & -1.060 \\
\hline$D E_{i t}$ & $?$ & 0.000 & 0.920 & 0.000 & -0.060 & 0.001 & 1.160 \\
\hline$L n M V_{i t-1}$ & $?$ & $-0.001 *$ & -1.620 & 0.000 & -0.470 & -0.001 & -1.580 \\
\hline$S T D \_R e t u r n n_{i t-1}$ & ? & $-0.158 *$ & -1.980 & $-0.417 *$ & -1.900 & -0.127 & -1.450 \\
\hline Specialist $_{i t}$ & $?$ & 0.000 & 0.360 & 0.002 & 0.710 & -0.001 & -0.600 \\
\hline OffSize $_{i t}$ & $?$ & 0.000 & 0.360 & -0.001 & -1.590 & 0.001 & 1.030 \\
\hline ClientImport $_{i t}$ & $?$ & 0.023 & 1.020 & $0.135 * * *$ & 3.310 & 0.006 & 0.240 \\
\hline Industry FE & $?$ & Included & & Included & & Included & \\
\hline Year FE & ? & Included & & Included & & Included & \\
\hline$F E R R \times M A S \_c l i e n t_{i t-1}$ & $?$ & -0.082 & -0.720 & $-0.196 * *$ & -2.260 & $-0.478^{*}$ & -1.780 \\
\hline FERR $\times$ Tax_client $t_{i t-1}$ & $?$ & -0.121 & -0.850 & $-0.432 * *$ & -2.480 & -0.014 & -0.070 \\
\hline$F E R R \times a b s F E R R$ & $?$ & -0.001 & -0.320 & 0.007 & 0.370 & 0.000 & 0.050 \\
\hline$F E R R \times$ Loss $_{i t}$ & $?$ & $-0.107 * *$ & -2.220 & $-0.245^{* * *}$ & -2.890 & $-0.135 * *$ & -2.540 \\
\hline${\text { FERR } \times \text { Restructure }_{i t}}$ & $?$ & -0.011 & -0.350 & -0.030 & -0.640 & 0.014 & 0.310 \\
\hline$F E R R \times D E_{i t}$ & $?$ & 0.000 & 0.120 & $0.010^{*}$ & 1.930 & -0.004 & -0.790 \\
\hline$F E R R \times L n M V_{i t-1}$ & $?$ & $0.032 * *$ & 2.240 & 0.028 & 1.340 & $0.031 *$ & 1.710 \\
\hline$F E R R \times S T D \_R e t u r n_{i t-1}$ & $?$ & -0.645 & -0.440 & -5.695 & -1.040 & -0.131 & -0.080 \\
\hline FERR $\times$ Specialist $_{i t}$ & $?$ & 0.027 & 0.690 & 0.001 & 0.010 & 0.036 & 0.640 \\
\hline FERR $\times$ OffSize $_{i t}$ & $?$ & -0.011 & -1.140 & 0.005 & 0.340 & -0.008 & -0.630 \\
\hline FERR $\times$ ClientImport $_{i t}$ & $?$ & 0.585 & 0.880 & $2.246^{* *}$ & 2.340 & 0.142 & 0.210 \\
\hline$F E R R \times$ Industry $F E$ & ? & Included & & Included & & Included & \\
\hline$F E R R \times$ Year FE & $?$ & Included & & Included & & Included & \\
\hline
\end{tabular}


This table reports the relation between Accounting Today's Top 100 accounting firms' provision of consulting services and clients' short-window (i.e., 3-day, centered on the earnings announcement dates) earnings response coefficients from 2000 through 2013 and broken out between pre-SOX (2000 through 2002) and post-SOX (2003 through 2013) periods. Panel A provides descriptive statistics and Panel B provides the results from estimating the OLS regression. *, **, and *** represent significance levels of 10 percent, 5 percent, and 1 percent, respectively, based on two-tailed p-values. See the Appendix for variable definitions. 
TABLE 6

Additional analyses on the effect of accounting firm consulting revenue on audit quality

Panel A: Change in \%MAS

\begin{tabular}{|c|c|c|c|c|c|c|c|}
\hline \multirow[b]{2}{*}{ Variable } & \multirow[b]{2}{*}{ Pred. } & \multicolumn{2}{|c|}{ DV $=$ Misstate } & \multicolumn{2}{|c|}{$\begin{array}{c}\text { Pre-SOX } \\
(2000-2002) \\
\text { DV = Misstate }\end{array}$} & \multicolumn{2}{|c|}{$\begin{array}{c}\text { Post-SOX } \\
(2003-2013) \\
\text { DV = Misstate }\end{array}$} \\
\hline & & Coeff. Est. & z-statistic & Coeff. Est. & z-statistic & Coeff. Est. & z-statistic \\
\hline$\Delta \% M A S_{j t-2 \text { to t-1 }}$ & $?$ & 0.011 & 0.170 & $1.049 * * *$ & 4.060 & $-0.200 * *$ & -2.160 \\
\hline MAS_client ${ }_{i t}$ & $?$ & $0.531 * * *$ & 3.270 & $0.350^{*}$ & 1.830 & $0.650 *$ & 1.850 \\
\hline Tax_client $_{i t}$ & $?$ & 0.150 & 0.940 & -0.017 & -0.070 & 0.139 & 0.710 \\
\hline Intercept \& Other Controls & & Included & & Included & & Included & \\
\hline Industry FE & & Included & & Included & & Included & \\
\hline Year FE & & Included & & Included & & Included & \\
\hline $\mathrm{N}$ & & 42,829 & & 7,588 & & 35,241 & \\
\hline Area under ROC curve & & 0.665 & & 0.675 & & 0.664 & \\
\hline
\end{tabular}

Panel B: Majority of revenues derived from MAS

\begin{tabular}{|c|c|c|c|c|c|c|c|}
\hline \multirow[b]{2}{*}{ Variable } & \multirow[b]{2}{*}{ Pred. } & \multicolumn{2}{|c|}{ DV $=$ Misstate } & \multicolumn{2}{|c|}{$\begin{array}{c}\text { Pre-SOX } \\
(2000-2002) \\
\text { DV = Misstate }\end{array}$} & \multicolumn{2}{|c|}{$\begin{array}{c}\text { Post-SOX } \\
(2003-2013) \\
\text { DV = Misstate }\end{array}$} \\
\hline & & Coeff. Est. & z-statistic & Coeff. Est. & z-statistic & Coeff. Est. & z-statistic \\
\hline MAS_50\% $\%_{j t-1}$ & $?$ & $0.344 * * *$ & 5.100 & $0.333^{* * *}$ & 4.770 & -1.096 & -1.540 \\
\hline MAS_client ${ }_{i t}$ & $?$ & $0.425 * * *$ & 2.960 & 0.257 & 1.530 & $0.622 *$ & 1.770 \\
\hline Tax_client $_{i t}$ & ? & 0.141 & 0.900 & -0.025 & -0.110 & 0.137 & 0.700 \\
\hline Intercept \& Other Controls & & Included & & Included & & Included & \\
\hline Industry FE & & Included & & Included & & Included & \\
\hline Year FE & & Included & & Included & & Included & \\
\hline $\mathrm{N}$ & & 46,864 & & 10,936 & & 35,928 & \\
\hline Area under ROC curve & & 0.663 & & 0.678 & & 0.664 & \\
\hline
\end{tabular}

Panel A presents the Accounting Today's Top 100 firms' provision of consulting services two years prior and the likelihood of client misstatements from 2000 through 2013 and broken out between pre-SOX (2000 through 2002) and post-SOX (2003 through 2013) periods. Panel B presents the relation between changes in firms' provision of consulting services and the likelihood of client misstatements for the same periods. Panel C presents the relation between different levels of the firms' provision of consulting services and the likelihood of client misstatements for the same periods. *, **, and *** represent significance levels of 10 percent, 5 percent, and 1 percent, respectively, based on two-tailed tests, unless a direction is predicted. See the Appendix for variable definitions. 